\title{
ARTICLES
}

\section{The First Amendment's Purpose}

\author{
Jed Rubenfeld*
}

I. THE PROBLEM IN CURRENT DoCTRINE..........................................................770

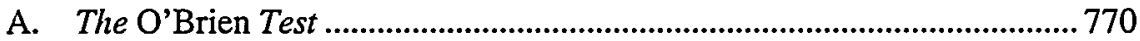

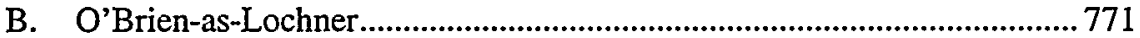

C. The Spence Test .......................................................................................... 772

D. The Centrality of Purpose in First Amendment Law ................................ 775

II. PURPOSIVISM-COSTS AND BENEFITS..............................................................778

A. First Amendment Absolutes ..................................................................... 778

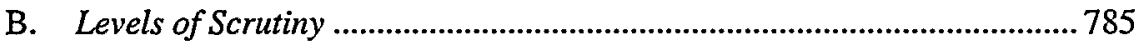

C. The Costs of Balancing, the Benefits of Purposivism .................................787

D. The Concept of State Purpose ................................................................... 793

III. PRACTICAL IMPLICATIONS: THREE ILLUSTRATIONS..........................................797

A. Begging................................................................................................ 798

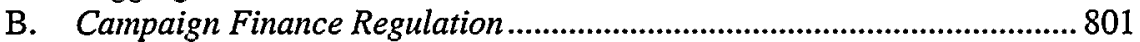

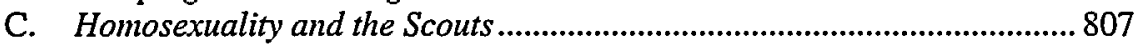

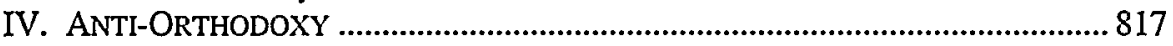

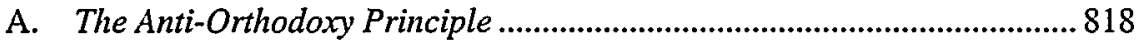

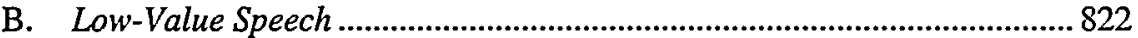

C. Clear and Present Danger.......................................................................... 826

D. Obscenity and Other Remaining Issues ....................................................... 830

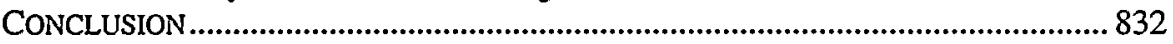

There is a problem in the basic structure of current free speech law. Consider two simple cases:

(A) $\mathrm{A}$ is ticketed for speeding. He claims a First Amendment violation. He argues - and this is his only argument-that a higher speed limit would have been safer and more fuel efficient.

(B) $\mathrm{B}$ is arrested for wearing a certain shirt. He claims a First Amendment violation. $\mathrm{He}$ argues-and the state concedes-that the legislature criminalized the wearing of such shirts solely because they bear a symbol expressing protest against state police practices.

* Slaughter Professor of Law, Yale Law School. 
Current doctrine gets these cases wrong. Believe it or not, under present Supreme Court case law, if $A$ can prove what he alleges, his First Amendment argument ought to prevail, while B's might well be dismissed for failure to state a claim.

Part I of this Article explains these doctrinal problems and shows how to solve them. The solution is not complicated. All the difficulties disappear as soon as First Amendment analysis takes up what the Supreme Court has ostensibly sought to foreclose: an open and direct inquiry into the law's purpose. This purposivist solution to A's and B's cases has significant implications for the basic structure of free speech law.

Part II describes these structural implications. Among other things, purposivism would eliminate most of the cost-benefit, balancing-test rhetoric so common in today's free speech jurisprudence. The language of balancing in First Amendment law, appealing as it may seem, is unacceptable in its implications and unnecessary in the cases where it is supposedly indispensable. Of course a person does not have a right to express his political opinions by car-bombing the White House, but contrary to conventional wisdom, this kind of example does not show that First Amendment rights have to yield to weighty state interests. It merely shows that a person who breaks a law not directed at speech can claim no constitutional immunity just because he was acting for expressive reasons. There is no First Amendment "pass" from a law whose purpose is not to punish speech.

Part III illustrates how purposivism would yield clear answers to specific First Amendment questions that today seem extremely difficult and contestable. Three questions are considered: the constitutionality of antibegging ordinances, of campaign-spending restrictions, and of antidiscrimination laws as applied to private associations. On the latter point, the Supreme Court's recent decision in Boy Scouts of America v. Dale upholding the Scouts' right to exclude homosexuals-will be discussed at length.

Boy Scouts is an extraordinary case. It appears to be the first case in Supreme Court history in which a party won a constitutional right to discriminate on free speech grounds. The Boy Scouts merited this exemption, a five-justice majority found, because New Jersey's prohibition of discrimination against homosexuals would have "significantly affect[ed]" the organization's ability to express its antihomosexual views. Indeed, the majority reasoned, New Jersey's law would have "force[d] the organization to send a message, both to the youth members and the world, that the Boy Scouts accepts homosexual conduct."2

1. 120 S. Ct. 2446 (2000).

2. Id. at 2454-55. 
Purposivism completely rejects the Boy Scouts decision, both in reasoning and result. In essence, the Boy Scouts' claim was a simple one. The Scouts wanted or needed to discriminate for expressive reasons. If they could not exclude homosexuals, they would not be able effectively - or as effectively-to express their sincerely held anti-homosexual views. The majority accepted this claim; the dissenters rejected it, on the facts.

But the Court should never have reached the facts. People constantly want to violate laws for expressive reasons. Tax protestors want to disobey the tax laws for expressive reasons. Every person and every organization that wants to discriminate probably has good expressive reasons for doing so. Discrimination is profoundly expressive. It is by far the most effective way most people have of expressing their view of the superiority of their own group and the inferiority of others.

Title VII has "significantly affected" the ability of countless employers to express their views about race or sex. Indeed, it forced them to "send a message" of equality that many presumably oppose (or would oppose if permitted to do so), in the same sense that New Jersey's law forced the Boy Scouts to do so. Should racist and sexist employers be able to come to court with First Amendment challenges to Title VII, demanding that judges accord them the same strict scrutiny that the Boy Scouts received? Should they at least be permitted to go to trial to present evidence that they have been discriminating not for commerical reasons (they prove that discrimination has actually been bad for business), but to communicate to their employees and to "the world" their sincerely held view that the races should not mix or that women belong in the home? Should a person who can prove that he genuinely holds anti-government views, and that refusing to pay taxes is his most effective or only effective means of communicating these views, be exempt from the income tax?

The answer to all these questions is no, and the reason is that there is no such thing as a free speech immunity based on the claim that someone wants to break an otherwise constitutional law for expressive purposes. The actor's purposes are not relevant to free speech analysis. The state's purposes, on the other hand, are dispositive. When a law is otherwise constitutional, and when an actor has not been singled out because of his expression, the actor has no free speech claim. The Boy Scouts were not singled out in this way. As a result, the Scouts' First Amendment claim should have been taken no more seriously than that of a tax protestor or that of a racist employer who demanded an exemption from Title VII on the theory that he wanted to discriminate for expressive, rather than merely commercial, reasons.

Finally, Part IV answers some obvious objections to free speech purposivism and enlarges on the overall conception of the First Amendment implied thereby. This conception is organized around what I will call an antiorthodoxy principle. It reintegrates the two strangely disjoined halves of the 
First Amendment: the freedom of speech and the freedom of religion.

A note of caution: I do not believe that purposivism can resolve all the questions free speech law has to answer. I am not even sure that purposivism can resolve the particular free spech questions I address here. But is worth trying to find out.

The purpose of purposivism is to reclaim an old idea: that there are certain First Amendment absolutes, which stand up regardless of any balancing of interests. Here is an example: no one can be punished for expressing himself on a matter of opinion. It makes no difference whether the subject matter is high (an opinion about the President) or low (an opinion about the weather), and it makes no difference what competing interests are at stake. What would it mean, against all the contemporary sentiment that there can be no such thing as a constitutional absolute, to reclaim this bedrock idea and take it to its conclusion? Can the idea be made good? If so, how much work can it do? These are the questions this Article tries to answer.

\section{THE PROBLEM IN CURRENT DOCTRINE}

\section{A. The O'Brien Test}

Current case law would analyze A's and B's claims under the so-called O'Brien test. O'Brien famously involved a man who burned his draft card as part of a public antiwar protest. O'Brien was subsequently convicted under a federal statute prohibiting the intentional destruction of Selective Service registration certificates. ${ }^{3}$ To decide the case, the $O^{\prime}$ Brien Court announced a four-factor test, under which a law regulating nonverbal but expressive conduct will be upheld:

[1] if it is within the constitutional power of the Government; [2] if it furthers an important or substantial governmental interest; [3] if the governmental interest is unrelated to the suppression of free expression; and [4] if the incidental restriction on alleged First Amendment freedoms is no greater than is essential to the furtherance of that interest. ${ }^{4}$

Applying these criteria, the Court affirmed O'Brien's conviction. According to the Court:

[T] he continuing availability to each registrant of his Selective Service certificates substantially furthers the smooth and proper functioning of the [Selective Service] system....

... We perceive no alfernative means that would more precisely and narrowly assure the continuing availability of issued Selective Service certificates than

3. United States v. O'Brien, 391 U.S. 367, 375 (1968).

4. Id. at 377 (bracketed numbers added). 
a law which prohibits their wilful mutilation or destruction. ${ }^{5}$

In what follows, I will ignore the first "prong" of the O'Brien test, and I will treat the last not as a genuine least-restrictive-means test, but as a narrow tailoring requirement satisfied so long as the challenged law does not "substantially" overburden speech. These qualifications should create no analytic distortion, because the first prong is analytically insignificant, and the last prong has been interpreted (or reinterpreted) to have the effect just described. ${ }^{6}$

$O^{\prime} B r i e n$ remains the leading case in this area. It continues today to furnish the basic structure for First Amendment analysis of "expressive conduct." And its test is deeply, demonstrably flawed.

\section{B. O'Brien-as-Lochner}

Return now to A, arrested for speeding. For simplicity of analysis, assume that A was driving on a highway where a federally mandated fifty-five mileper-hour speed limit had recently replaced a sixty-five mile-per-hour limit. Say that $\mathrm{A}$ was driving at sixty-five. Assume that the lower speed limit was adopted to serve two (and only two) state interests: improving highway safety and conserving fuel.

A's First Amendment argument invokes O'Brien's second factor: He says that the lower speed limit does not in fact "further[] an important... governmental interest." He has a team of trafficologists prepared to testify that a fifty-five mile-per-hour speed limit actually increases highway fatalities, while decreasing fuel efficiency. The judge agrees that $O^{\prime} B r i e n$ obliges him to conduct a trial on these issues. For if A's allegations are true, then the speed limit does not substantially further important governmental interests. After a month-long hearing, the judge finds in A's favor and strikes down the speed limit as a First Amendment violation.

What is wrong with this picture?

Something obviously is wrong. The First Amendment has here become a vehicle for constitutionalizing a policy question of purely legislative dimensions. If in a case like $A^{\prime} s, O^{\prime} B r i e n$ really called for judicial superlegislative review of whether a particular speed limit serves its policy objectives well enough to be sustained, then the O'Brien test would be something like Lochner v. New York all over again. To save words, call this the O'Brien-as-Lochner result.

But what exactly is the mistake being made here? Where did the judge go

5. Id. at 381 .

6. See, e.g., Tumer Broad. Sys., Inc. v. FCC, 512 U.S. 622, 662 (1994) (omitting the first factor entirely and affirming a more lenient interpretation of the last). 
wrong, and how was he supposed to avoid the O'Brien-as-Lochner result?

Here is the answer that will have already occurred to most readers: A was not speaking. His conduct was not "expressive," and therefore he never stated a First Amendment claim at all. That is why the judge should not have entertained A's claims.

This is in fact the escape route from O'Brien-as-Lochner offered by current doctrine. As the Supreme Court has reemphasized in subsequent cases such as Texas $v$. Johnson, a flag-burning decision, the O'Brien test is not triggered—indeed no First Amendment scrutiny is triggered-if the defendant was not engaged in "expressive conduct." "We must first determine whether [defendant's acts] constituted expressive conduct, permitting him to invoke the First Amendment...." If not, the First Amendment is not implicated. The "particular conduct" at issue must "possess[] sufficient communicative elements to bring the First Amendment into play."

But suppose A says that his conduct was expressive. Suppose he says that driving fast is how he "expresses himself." Or that he was "expressing disagreement" with the federally mandated speed limit. Or that his speeding was "performance art." To all these claims, current doctrine offers a relatively clear answer, which at first blush seems cogent. Another test, the so-called Spence test, determines when nonverbal activity qualifies as "expressive conduct."

\section{The Spence Test}

The Spence test demands that two criteria be satisfied before nonverbal conduct will be recognized as sufficiently "communicative" to trigger First Amendment scrutiny. "In deciding whether particular conduct possesses sufficient communicative elements to bring the First Amendment into play, we have asked whether 'an intent to convey a particularized message was present, and whether the likelihood was great that the message would be understood by those who viewed it."'10 Relying on Spence, a judge could be expected to find that A cannot get through the First Amendment door. Even if A intended to convey a "particularized message" by speeding, there was no "great likelihood" that viewers would understand this message, whatever it was. As a result, A cannot "bring the First Amendment into play."

So that is how current doctrine ostensibly avoids the O'Brien-as-Lochner result. A person trying to invoke the O'Brien test has to satisfy Spence. In typical situations, like A's, Spence will not be satisfied. Doesn't Spence

7. Texas v. Johnson, 491 U.S. 397, 403-04 (1989).

8. Id. at 403 .

9. Id. at 404 .

10. Id. at 404 (quoting Spence v. Washington, 418 U.S. 405, 410-11 (1974)). 
therefore offer a sound answer to the problem of Case A described above?

No. Spence does not solve the problem at all. For three reasons.

First, Spence is a profoundly unsatisfactory test for deciding what nonverbal stuff counts as sufficiently "expressive" to trigger First Amendment scrutiny. Art, for example, defies the Spence test. The Supreme Court has recognized this: "[mf confined to expressions conveying a 'particularized message," the First Amendment "would never reach the unquestionably shielded painting of Jackson Pollock, music of Arnold Schoenberg, or Jabberwocky verse of Lewis Carroll."11 This point may seem to have no bearing on A's claim. But it does bear. For unless courts are to wall off art as its own special First Amendment category to which Spence does not apply-a highly unappealing idea, unless you think judges could successfully determine what is and is not art-then we are obliged to recognize that the Spence test merely states sufficient, not necessary, criteria for determining if conduct is expressive.

But that means that A could have a claim after all when he says his driving was "expressive." Perhaps driving fast really is how he "expresses himself." Perhaps A really was engaging in "performance art"-maybe highperformance art.

In all seriousness, the idea that speeding is "expressive" is in no way absurd. Remember that the difficulty here is that if $A$ was engaged in "expressive" conduct, current doctrine has no clear escape from the O'Brienas-Lochner result. The Spence test would seem to take care of this problem, but that is only because Spence adopts a wholly artificial definition of what nonverbal actions count as expressive. Modern dance, for example, could not pass Spence. To be sure, the Supreme Court would undoubtedly strike down a ban of modern dance, and would probably do so under the O'Brien test, but that is only because the Court would, without mentioning it, forget in such a case that the O'Brien doctrine is not supposed to be triggered if Spence is unsatisfied.12 Once Spence's particularized-message test is seen no longer as a necessary condition, but only as a sufficient condition, of expressiveness, the assertion that speeding is not expressive actually becomes rather mysterious. For who can doubt that A, flying along in his orange convertible Porsche 914, is expressing something, and who can doubt that there is an audience "reading" this expression? Needless to say, if speeding is expressive conduct, nearly every action we take is or could be expressive. But that is the problem, not the solution.

The second reason why Spence does not solve the O'Brien-as-Lochner

11. Hurley v. Irish-American Gay, Lesbian and Bisexual Group of Boston, 515 U.S. 557,569 (1995).

12. See, e.g., Barnes v. Glen Theatre, Inc., 501 U.S. 560 (1991) (plurality opinion) (applying $O^{\prime}$ Brien to a prohibition of nude dancing in nightclubs; no sign of Spence). 
problem is still more important. An individual arrested for engaging in prohibited conduct should not be required to show that his conduct was "expressive" before he can raise First Amendment claims. Here we arrive at the case of B, described above, who was arrested for wearing a shirt.

Imagine that New Yorkers begin wearing a shirt with a certain symbol on the chest to protest city police practices. The city council then enacts an ordinance criminalizing the wearing of such shirts. Stipulate that the ordinance is passed solely and avowedly because of the shirts' protest message. B is arrested for wearing the offending shirt. But as it turns out, the hapless B just recently arrived in New York from Idaho. He bought the shirt because he thought it looked cool. He had no idea of the "particularized message" it conveyed. Under current doctrine, B goes to jail. He has no First Amendment claim.

Once again, I am not saying that courts today would clearly reject B's First Amendment claim. I hope and expect they would sustain it. The point, however, is that current doctrine not only lacks the conceptual resources to reach this result, but actually cuts against it. Having had no intention to communicate any particularized message, B's conduct would not be "expressive" under Spence, and B would therefore be unable to "bring the First Amendment into play." Having neither literally spoken nor engaged in expressive conduct, B would not be "permitt[ed] to invoke the First Amendment" at all. ${ }^{13}$

Finally, Spence cannot dispose of A's case because A did satisfy the Spence test. Perhaps I forgot to mention it: On the roof of A's car, there was a huge sign saying, "If you see me driving at 65 , it means I'm protesting the 55 mile-per-hour speed limit." Such a sign allows A fully to establish both Spence criteria. A was speeding-to-speak: He had a particularized message, and, circumstances permitting, there was every likelihood that his message would be understood.

For this third reason alone, Spence provides no escape route from the

13. This reasoning is not speculative. In a series of cases involving discharges of public employees, federal appellate courts, relying on Spence and on the Supreme Court language just quoted, have dismissed First Amendment claims: (1) where the employees alleged that their supervisors fired them solely as retaliation for the employees' having engaged in protected expression; (2) where this allegation was assumed true for purposes of decision; but (3) where the plaintiffs conceded that the supervisors had been under a misimpression-the employees had not in fact engaged or meant to engage in the expression for which the retaliation was (mistakenly) made. In the words of the Fifth Circuit, the employee in these circumstances had not made a statement of any sort; her First Amendment claim had to be dismissed, therefore, because she had "not alleged that she engaged in any expressive conduct potentially subject to First Amendment protection." Jones v. Collins, 132 F.3d 1048, 1054-55 (5th Cir. 1998); accord, e.g., Fogarty v. Boles, 121 F.3d 886 (3d Cir. 1997). This situation is analytically identical to B's case: $B$ is arrested for engaging in expressive conduct that he was not, at least under Spence, engaged in. 
O'Brien-as-Lochner result. Nearly anyone violating any law will be able, with a little ingenuity, to pass the Spence test. Anyone will then be able to demand, under O'Brien, a full-blown judicial determination of whether the law he violated actually furthers (or "substantially" furthers) important governmental interests.

To summarize, current First Amendment doctrine makes problematic two cases that ought to be extremely easy. First, taken at its word, current doctrine allows A to convert an ordinary traffic violation into a Lochner-like exercise in constitutional review of a law's policy merits. Second, it condemns to jail the hapless $B$, arrested for wearing a protest shirt whose message he did not understand.

What is the mistake being made here, and how is it to be resolved?

\section{The Centrality of Purpose in First Amendment Law}

To see where Spence and $O^{\prime} B r i e n$ go wrong, look a little more closely at the latter case. O'Brien contended that Congress's real purpose in prohibiting the destruction of draft cards was to target antiwar protesters. This contention was entirely plausible, ${ }^{14}$ but the O'Brien Court explicitly and emphatically dismissed it as irrelevant. "It is a familiar principle of constitutional law that this Court will not strike down an otherwise constitutional statute on the basis of an alleged illicit legislative motive." 15 "[U]nder settled principles the purpose of Congress... is not a basis for declaring this legislation unconstitutional."16

In fact, under "settled principles" an impermissible legislative purpose undoubtedly can render an otherwise valid law unconstitutional. This is particularly clear in equal protection cases. ${ }^{17}$ The more interesting point, however, is that the $O^{\prime} B r i e n$ test itself is centrally concerned with legislative

14. See, e.g., Dean Alfange, Jr., Free Speech and Symbolic Conduct: The Draft-Card Burning Case, 1968 Sup. CT. REv. 1, 15-16:

What emerges with indisputable clarity from an examination of the legislative history of the amendment is that the intent of its framers was purely and simply to put a stop to this particular form of antiwar protest, which they deemed extraordinarily contemptible and vicious-even treasonous-at a time when American troops were engaged in combat. Id. at 15.

15. O'Brien, 391 U.S. at 383.

16. Id.

17. See, e.g., Washington v. Seattle School Dist. No. 1, 458 U.S. 457, 471 (1982) (striking down formally race-neutral law enacted by statewide referendum where "despite its facial neutrality there is little doubt that the initiative was effectively drawn for racial purposes"; it was "beyond reasonable dispute, then, that the initiative was enacted "because of," not merely "in spite of," its adverse effects upon"" a racial minority). See also text accompanying notes 50-56 infra (discussing the Ho Ah Kow case and judicial devices for smoking out illegitimate state purposes). 
purpose, despite the Court's protests to the contrary.

Determining the purpose to be attributed to state action is in a sense the entire point of the $O^{\prime} B r i e n$ test, which inquires into the "governmental interest" the law is supposed to serve, asks whether this "interest" is "related" "to the suppression of free expression," and scrutinizes the law to ensure that its provisions are narrowly tailored to serve this interest. ${ }^{18}$ In fact, in deciding that Congress's "interest" in prohibiting draft-card destruction was "limited to the noncommunicative aspect of [the] conduct," the O'Brien Court distinguished a prior case on the ground that the prior case involved a "statute... aimed at suppressing communication." ${ }^{19}$ Aim is of course a synonym of purpose. If the ultimate question, then, as the Court's own language suggests, is whether the statute in question was "aimed" at punishing dissent, then the real function of the $O^{\prime} B$ rien test is nothing other than ascertaining the law's purpose..$^{20}$

\section{As it should be.}

A's and B's cases are solved the moment we allow into First Amendment analysis what the $O^{\prime}$ 'Brien Court strained unsuccessfully to foreclose: an open and direct look at governmental purpose. The only real First Amendment question in these cases is whether the state's purpose was to punish someone for speaking.

What does it mean to be punished for speaking? It does not mean being punished as a result of speaking, which happens all the time. Someone refuses to pay his taxes. His refusal to pay may well have been a speech act; he may have been, through his conduct, intentionally communicating a host of specific or general messages of political dissent. The fact that his actions were expressive, however, gives him no First Amendment immunity. He can be prosecuted as a result of his speech act, so long as he is not punished for speaking. In other words, so long as the Internal Revenue Service does not, say, single him out because of what his actions communicated, and so long as, under the generally applicable tax laws, the communicativeness of his actions has no bearing on his liability, he can be punished for what he did, regardless of what he might have been saying through what he did.

Spence asks whether the action at issue was expressive, and this question

18. O'Brien, 391 U.S. at 377.

19. Id. at 381-82 (emphasis added).

20. Over twenty-five years ago, Paul Brest suggested that $O^{\prime} B r i e n ' s$ real teaching, despite the Court's contrary language, was that "some motives are unconstitutional." Paul Brest, The Conscientious Legislator's Guide to Constitutional Interpretation, 27 STaN. L. REv. 585, 590 (1975) (emphasis added). Elena Kagan, in a penetrating and persuasive article, has made a similar point not only about $O^{\prime} B$ rien, but about the entire structure of contemporary free speech doctrine. See Elena Kagan, 63 U. CHI. L. REv. 413, 414 (1996) (" $[N]$ otwithstanding the Court's prostestations in $O^{\prime}$ Brien,.... First Amendment law, as developed by the Supreme Court over the past several decades, has as its primary, though unstated, object the discovery of improper governmental motives."). 
puts the focus on the individual's purpose in acting. In effect, Spence asks whether an individual was speaking (or attempting to speak) through his conduct. By contrast, in deciding what the person is being punished for, the focus is on the state's purpose: either the purpose of the law that was violated or, in an appropriate case, the purpose of those enforcing it.

Whether a person is being punished for speaking, rather than as a result of it, depends on the kind of wrong or harm that the state seeks to prevent. Some harms arising out of our actions are independent of whatever we might be expressing through those actions. A speeding driver creates safety risks to others regardless of whether he is speeding-to-speak and regardless of what he might be trying to express thereby. But other harms are communicative; the communicativeness of the action is a but-for cause of the harm. There are many kinds of harm or alleged harm that arise out of communication. The message communicated might be said to be immoral. Or the message might annoy or alarm its audience. Or the communication might be effective and lead others to take actions harmful either to themselves or others.

The First Amendment is implicated when the government makes communicative harm the basis for liability. ${ }^{21}$ This is so not only with respect to laws regulating "expressive conduct," but with respect to laws directly regulating speech. Indeed this is why the distinction between "content-based" and "content-neutral" regulations is so important to First Amendment law. Because a content-based regulation makes communication itself an element of the prohibited act, the communication effected by the act must be a but-for cause of whatever wrong or harm the regulation is supposed to prevent.

The point is not that the government acts unconstitutionally whenever it addresses communicative harms. Fraud laws, for example, typically target communicative harms. I will address fraud below, together with other kinds of speech acts that can be constitutionally prohibited. The point for now is that if the state punishes someone solely for doing noncommunicative harm, the person is not punished for speaking. And if a person is not punished for his

21. For an argument similar in some important respects but different in others, see Thomas Scanlon, A Theory of Freedom of Expression, 1 PHIL. \& PUB. AFF. 204 (1972). On Scanlon's theory, the core principle of free speech is that "certain harms" potentially caused by an individual's acts "cannot be taken as part of a justification for legal restrictions on these acts." Id. at 213. According to Scanlon, the excluded harms are: (1) inducing others to hold false beliefs; and (2) persuading others to take harmful actions. Id. Unfortunately, with the excluded harms thus specified, Scanlon's principle generated insuperable difficulties. For example, it immunized fraudulent advertising, while failing to protect speech that a majority simply found offensive. For these and other reasons, Scanlon later abandoned his earlier position. See T.M. Scanlon, Jr., Freedom of Expression and Categories of Expression, 40 U. PrrT. L. REv. 519, 530-32 (1979). Despite its difficulties, Scanlon's first article remains, to my mind, the superior of the two. It correctly oriented free speech analysis toward the state's reasons (or, in my terms, purposes) for acting. Its flaw lay in an improper specification of the excluded harms. 
speech, his freedom of speech has not been violated.

When a person is prosecuted in the ordinary course for violating an ordinary prohibitory law, he will have no First Amendment claim because he will not be punished for speaking, even if he was speaking (or trying to speak) through his illegal conduct. Conversely, if the state's purpose was to punish him for speaking, then his First Amendment rights will be implicated-even if he was not speaking. This simple line of thought completely and satisfactorily answers A's and B's cases.

(A): Even if A really was speeding-to-speak (with the sign attached to his car), he still has stated no First Amendment claim because his evidence about highway fatalities and fuel efficiency is constitutionally irrelevant. No matter how persuasively this evidence may prove that the fifty-five mile-per-hour speed limit was a stupid law, A would still have proved only that the speed limit was-a stupid law. His evidence would not remotely raise a colorable inference that the law had been passed in order to target speech or that the police had selectively targeted him because of his speech. That is why a judge could and should dismiss A's allegations for failure to state a claim.

To be sure, in certain circumstances, a challenge to the putative public policy interests behind a law could raise an inference that speech was the real target. Such a case was O'Brien itself. But as we have seen, the O'Brien Court precisely did not want to face this issue and as a result left us with a deeply unsatisfactory articulation of First Amendment doctrine.

(B): By contrast, B does have a valid First Amendment claim, even though he was not trying to say anything. The individual's purpose is irrelevant here; the state's purpose is dispositive. And the state's purpose, by stipulation, was to punish political dissent. That is the end-or should be the end-of B's case. The First Amendment does not permit any state action undertaken to punish someone for expressing political dissent. Period.

\section{PURPOSIVISM-COSTS AND BENEFITS}

I want to stress that "period," because a purposivist First Amendment jurisprudence, of the kind I am proposing, would demand a full stop here that current doctrine does not recognize. As a result, it calls for a reconceptualization of the basic structure of free speech law.

\section{A. First Amendment Absolutes}

Here is what I mean. What happens, under today's case law, if a court applying $O^{\prime} B r i e n$ determines that the state interest behind a particular law is "related to the suppression of free expression"? For example, what happens under current doctrine if a court determines that a state has criminalized the 
burning of flags solely because of the message communicated thereby?

The answer is not that the law is therefore unconstitutional period. Instead the $O^{\prime} B r i e n$ test here yields to a more stringent standard of review. If the "State's regulation is related to the suppression of free expression ... then we are outside of $O^{\prime}$ Brien's test, and we must ask whether" the law is "justifie[d]" "under a more demanding standard."22 Under this "more demanding standard," usually called strict scrutiny, the law will be struck down unless it is "narrowly tailored" to further a "compelling state interest."23

The compelling state interest test is undoubtedly an exacting standard of review, but it is still not the same as holding a law unconstitutional period. The significance of the difference can be described as follows. A purposivist view of the First Amendment does not involve balancing. It is absolute. It does not purport to determine if the constitutional "costs" in a given case are "outweighed" or "justified" by the governmental "benefits."

Contemporary First Amendment opinions, especially in their deployment of strict scrutiny and other, intermediate levels of review, are loaded with the rhetoric of balancing -of deciding whether First Amendment "burdens" are "justified" in a given case by countervailing state interests. Buckley v. Valeo, the famous campaign finance case, offers a particularly clear example. According to the Buckley Court, "the governmental interest in preventing corruption and the appearance of corruption," although "weighty," was "inadequate to justify" the "severe restrictions on protected freedoms" effected by campaign spending caps. ${ }^{24}$ The Supreme Court's recent decision involving homosexuality and the Boy Scouts offers another clear example. ${ }^{25}$

One of the best expositions of the balancing-test approach to First Amendment law can be found in a concurring opinion written by Judge Richard Posner. ${ }^{26}$ Confronted with a law banning nude dancing in nightclubs, and meditating with considerable force on the protected status of art under the First Amendment, Posner concludes that constitutional protection must extend to high and low cultural forms alike, from classical ballet to erotic dancing. Why? Because Posner sees the folly of "letting judges play art critic." Posner denies-quite persuasively-that judges can make plausible measurements of "expressive value" or "aesthetic quality." "[M]uch of today's high culture began as popular entertainment .... The practical effect of letting judges play art critic and censor would be to enforce conventional notions of 'educated taste,' and thus to allow highly educated people to consume erotica but forbid

22. Texas v. Johnson, 491 U.S. 397, 403 (1989).

23. United States v. Eichman, 496 U.S. 310, 318 (1990).

24. Buckley v. Valeo, 424 U.S. 1, 23, 29, 45 (1976).

25. See Part III.C infra.

26. Miller v. Civil City of South Bend, 904 F.2d 1081, 1089-1104 (7th Cir. 1990) (Posner, J., concurring), rev'd sub nom. Barnes v. Glen Theatre, Inc., 501 U.S. 560 (1991). 
hoi polloi to do the same."27

At this point, however, Posner's reasoning takes a strange and interesting turn. Having established that "high" and "low" culture should not be distinguished for First Amendment purposes, Posner raises the question of bullfighting. Why can bullfighting be constitutionally prohibited? Bullfighting, Posner vividly reminds us, is clearly "expressive":

There is music, pageantry, elaborate costumes, the march of the toreadors, the dance-like steps with which the matador incites and parries the bull, the picadors on their splendidly caparisoned prancing horses. The whole is orchestrated and choreographed for maximum emotional impact; among the feelings conveyed are grace, courage, suffering, fear, beauty, cruelty, splendor, and machismo.... Is [bullfighting] therefore protected by the First Amendment? It is not; the First Amendment no more forbids the prohibition of bullfighting than it does the prohibition of obscenity. ${ }^{28}$

But how can this be? Is it because bullfighting, although expressive, is less expressive than protected cultural genres such as ballet? No, says Posner; the answer lies rather in bullfighting's harms:

The difference between bullfighting and ballet has nothing to do with expressiveness; they are equally expressive, albeit of a different range of emotions. The pertinent difference is that ballet does not entail the torture and killing of animals or a high risk of injury or death to the dancers, and bullfighting does. ${ }^{29}$

From this observation, Posner draws the conclusion that First Amendment protection depends on a balancing of interests, a cost-benefit test in which harms have to be weighed against expressive value. "The Constitution does not place freedom of expression above all other values.... Bullfighting is forbidden not because it is not expressive, but because in American society its harmful consequences are thought to outweigh its expressive value."30

The latter proposition is the one I am calling into question. On first blush, it seems natural, almost inevitable. Surely the reason why bullfighting is prohibited lies in the skewering of bulls for entertainment value. And if this or any other of bullfighting's harms renders it unprotected, then surely the exclusion of bullfighting from First Amendment protection must boil down to a judgment that its harms "outweigh its expressive value."

We should wonder at this reasoning. Can it really be the case that otherwise protected expression becomes prohibitable whenever "in American society its harmful consequences are thought to outweigh its expressive value"? If so, there would be no freedom of speech to speak of. Even peaceful political

27. Id. at 1098 .

28. Id. at 1097.

29. Id.

30. Id. (emphasis added). 
protest could then be banned, and it could be banned precisely at times when the First Amendment's protection would be essential. In 1968, for examplethe year O'Brien was decided-it may well have been the case that "in American society" the "harmful consequences" of antiwar protest were "thought to outweigh its expressive value." Surely this was the "thought" of "American society" in 1919, when the United States Supreme Court upheld the conviction of a war protester named Abrams, over the lone voice of a dissenting Justice who wrote that the defendant "had as much right to publish" his socialist opinions "as the Government has to publish the Constitution of the United States." 31

At an absolute minimum, judges would have to review "society's" judgments that the "harmful consequences" of a particular speech act or speech category "outweigh its expressive value." But once the cost-benefit determination is no longer attributed to the amorphous sentiments of "American society," and is instead said to be a task for judges, the balancing of harms against benefits becomes even harder to make intelligible. How exactly is a judge to decide whether the cost of torturing bulls "outweighs" the "expressive value" of bullfighting (a difficulty that must be especially pronounced when the judge has already acknowledged that he cannot measure "expressive value")? With Posner, it is just conceivable that we are supposed to envision a judge adding up the dollars that individuals are willing to spend to see bullfighting, subtracting the social costs of gored toreadors and tortured bulls, and so on. But what is the social cost, incidentally, of a tortured bull?

Most people find the rhetoric of balancing very congenial in First Amendment contexts. I will say more about its defects below. The point for now is just this: A purposivist First Amendment jurisprudence offers a wholly different and much simpler answer to Posner's conundrum.

Bullfighting is prohibitable not because of any balancing of "social costs" against First Amendment "benefits." It is prohibitable because (and only to the extent that) the torturing of bulls can be banned without reference to what it communicates. Persons caught bullfighting are no differently situated than A, caught speeding, or than income eamers caught evading their taxes. All these individuals may be engaging in expressive activity. But they are punished for their conduct, not for what they are saying through that conduct.

Make no mistake: Torturing bulls is not only expressive; it may be harmfully expressive. At least some people might think so. Perhaps bullfighting communicates a harmful set of attitudes about the worth of animals or the moral status of their suffering. But these harms-the ones that arise from what bullfighting communicates-are precisely the ones on the basis of which bullfighting cannot constitutionally be prohibited. An animated or

31. Abrams v. United States, 250 U.S. 616, 629 (1919) (Holmes, J., dissenting). 
simulated bullfight is not prohibitable, even if it inflicts these same communicative harms, and even if "society" as a whole has deemed that these "harmful consequences" outweigh its "expressive value."

From the balancing point of view, the determination of whether animated bullfights are prohibitable should be thoroughly and problematically factintensive, dependent on numerous difficult empirical measurements of harms and benefits, either directed specifically to animated bullfighting or to the "speech category" into which animated bullfighting falls-a question that raises imponderable difficulties of its own. (Is it art? "political" speech? merely "entertainment"?) But from a purposivist perspective, no such balancing of interests is necessary. If a legislature bans animated bullfighting because of the harm allegedly done by the moral or emotional attitudes that it communicates - and with an animated bullfight, there can be no harm plausibly at issue other than the harm allegedly done by what is communicated-the legislature has acted unconstitutionally. Period.

There will be resistance to the idea that balancing can really be avoided in First Amendment cases. Doesn't everyone know, as Posner says and as the Supreme Court has repeatedly held, that First Amendment rights are not absolute? Even the right to engage in political dissent must surely yield when compelling governmental interests are implicated. After all, my right to express my political opinion of the President does not entitle me to car-bomb the White House. Doesn't this kind of case prove that First Amendment rights must always be balanced against "society's interests" and give way when those interests are sufficiently "compelling"?

No. Purposivism disposes of this kind of hypothetical-the kind that is invariably invoked to prove the necessity of balancing in First Amendment law-without any balancing whatsoever. Of course a person has no right to express his political opinions by car-bombing the White House. But the reason is not that the car-bomber's First Amendment right is overridden by countervailing governmental interests. We should not say: The prosecution of the car-bomber transgresses a First Amendment norm, but is constitutional anyway because it passes "strict scrutiny" and is therefore "justified" by the state interests at stake. On the contrary, there is no transgression of any First Amendment norm in such a case at all.

A person arrested for trying to car-bomb the White House need not, and should not, be arrested for what he is saying. He can, however, be arrested for what he is doing.

An old line of First Amendment argument sought to solve the speech/conduct conundrum by determining whether the "conduct element" or the "speech element" "predominated" in any given action. As Emerson put it, if the "expressive element" "predominated," the First Amendment was 
supposed to offer protection; if not, there was no protection. ${ }^{32}$ I am not resurrecting this old, notoriously faulty line of analysis. ${ }^{33}$ So long as we ask what kind of action (expression or conduct?) the individual was engaging in, we will get nowhere. This conclusion does not mean, however, that we cannot cogently ask whether the car-bomber is being prosecuted for the expressiveness of his conduct.

First Amendment scholarship is littered with would-be critical theorizing that, having correctly recognized the impossibility of carving up our actions dichotomously into speech and conduct, eagerly jumps to the conclusion that First Amendment analytics are thereby wholly undermined. Here, for example, is Pierre Schlag, after making the perfectly credible point that most or all speech acts are "performative" (meaning that they do things in the world), while most or all conduct is "expressive":

Now while this point has epidemic implications difficult to cabin, it is also the sort of point that is forgotten over and over again in the academic First Amendment literature. It is a point which, in order for standard liberal First Amendment literature to sustain itself, must be forgotten over and over again. Indeed, forgetting this point is a pre-condition to doing standard liberal First Amendment thought. To put it another way, if you are the sort of person who cannot tell the difference between action and expression or their substitute homologies, you simply cannot do standard liberal First Amendment thought..$^{34}$

Schlag is right only if "standard" First Amendment thought is in the grip of the Emersonian analysis mentioned above. According to this analysis, so long as a person is engaging in expression, rather than mere conduct, he can claim First Amendment protection when the government tries to get in his way. From this perspective, the whole free speech edifice does indeed rest on the possibility of determining in every case whether the person's actions amounted to expression or conduct. This analysis, which organizes Schlag's entire argument, ${ }^{35}$ cannot be successfully worked through. We routinely, irreducibly,

32. See, e.g., THOMAS I. EMERSON, THE SYSTEM OF FREEDOM OF EXPRESSION (1970); ThOMAS I. EMERSON, TOWARD a GENERAL THEORY OF THE FIRST AMENDMENT 17 (1966).

33. Ely is supposed to have given the definitive rebuttal: "[B]uming a draft card to express opposition to the draft is an undifferentiated whole, $100 \%$ action and $100 \%$ expression.... Attempts to determine which element 'predominates' will therefore inevitably degenerate into question-begging judgments about whether the activity should be protected." John Hart Ely, Flag Desecration: A Case Study in the Roles of Categorization and Balancing in First Amendment Analysis, 88 HARV. L. REV. 1482, 1495 (1975). Ely also noted the possibility of a purposivist First Amendment jurisprudence as an alternative to the conduct-expression distinction. Id. at 1496-97.

34. Pierre Schlag, How To Do Things with the First Amendment, 64 U. COLO. L. REV. 1095, 1100 (1993).

35. See id. at 1099-1100 ("I thought Emerson had developed a truly great theory ... . I was hoping the theory would hold up. But it was not to be."). A virtually identical argument, with virtually identical flaws, can be found in Paul F. Campos, Advocacy and 
and sometimes simultaneously do things with words and say things with actions. But none of this threatens a purposivist First Amendment.

If I am ticketed for speeding, an Emersonian First Amendment jurisprudence, obliged to deny my conduct's "expressiveness," will be legally shallow and culturally jejune. But a jurisprudence denying that I was ticketed for my expression may simply be-correct. In the ordinary course, I will have no plausible claim that I was singled out (from other speeders) because of something I was expressing. If instead I claim that the legislative purpose behind the speed limit is to target speeding's communicative harms (as opposed, say, to the costs of accidents), my claim will be equally implausible.

Perhaps it will be said that speed limits do target speeding because of something speeding expresses: reckless indifference to the safety of others. The word "expresses" in this sentence has, however, undergone a subtle but significant change. If A causes B's death through actions "expressing" an intention to kill, A may be punishable for murder. With this use of "expression" in mind, someone might begin to think that ordinary homicide laws implicate the First Amendment. Don't they punish "expression"? Aren't they in fact content-based suppressions of "expression"? The answer is yes, but only when "expression" is used in such a way that it no longer means speech. A is not punished for communicating his intention; he is punished for acting on it. Acting on an intention to kill is not the same as communicating that intention. One who intentionally kills might, for example, never communicate his intention to anyone. His actions may still "express" his intention, but only where "expressing" essentially means "manifesting," as a scientist might speak of phenotypes "expressing" a certain gene. Laws that attach liability to actions "expressing" a certain mens rea no more implicate the First Amendment than does a law requiring a dog to be put to death if it shows signs of ("expresses") rabies. This is why "hate crimes" laws are correctly upheld against First Amendment challenges, while "hate speech" laws are correctly struck down. ${ }^{36}$

A person made liable under a prohibitory law is punished for speaking if and only if: (1) the law makes the fact that he was communicating an element of the prohibited offense; (2) the legislative purpose was to target speech even though the prohibition is speech-neutral on its face; or (3) the law was selectively enforced to target speech. If none of these three conditions holds, then the person will have no free speech claim at all, no matter how expressive his words or actions were.

Scholarship, 81 CAL. L. REv. 817, 844-45 (1993).

36. Compare Wisconsin v. Mitchell, 508 U.S. 476 (1993) (upholding supplemental punishment where assault victim was chosen because of his race), with R.A.V. v. City of St. Paul, 505 U.S. 377 (1992) (invalidating hate speech ordinance). The former punishes persons for acting on a certain mental state; the latter punish persons for communicating it. 


\section{B. Levels of Scrutiny}

The distinction between a cost-benefit, balancing approach to First Amendment "interests" and a more absolute, purposivist approach brings into view a profound inner tension in the structure of free speech doctrine. Current free speech law, like current equal protection law, is almost obsessively organized around the proliferation of well-known "standards of review" or "levels of scrutiny." The O'Brien test is one such standard of review. Another, quite similar "intermediate" standard is the "time, place, and manner" test, which applies to content-neutral speech regulations. The most demanding standard of review is "strict scrutiny." Very generally, these different levels of review tend to boil down to "narrow-tailoring" inquiries of various kinds and varying degrees of exactingness.

There is very little scholarship on, and no doctrinal explanation whatsoever of, the reason why free speech and equal protection jurisprudence should share the same basic structure, organized around similar standards of heightened scrutiny. To understand this connection, observe that all these narrow-tailoring tests can be understood in two quite different ways.

The first is to see them as cost-benefit balancing tests, with an increasing amount of benefits demanded as the level of scrutiny ratchets up. This is how judges often present them and how commentators often regard them. ${ }^{37} \mathrm{~A}$ particularly clear example can be found in the Supreme Court's recent affirmative action decisions.

The costs of race-based minority preferences are so high, the justices have repeatedly said, that strict scrutiny must be applied to ensure that these costsespecially the inadvertent fostering of stereotypes of racial inferiority-are justified by compelling state interests. ${ }^{38}$ This is strict scrutiny explained in cost-benefit, justificatory terms: Racial classifications cause very significant harms, but these harms can be outweighed in an appropriate case if the offsetting benefits are high enough. As the Court explained in the well-known

37. See, e.g., Richard H. Fallon, Jr., The Supreme Court, 1996 Term-Foreword: Implementing the Constitution, 111 HARV. L. REV. 54, 78-79 (1997).

38. See, e.g., Bush v. Vera, 517 U.S. 952, 984 (1996) (plurality opinion) ("[W]e subject racial classifications to strict scrutiny precisely because that scrutiny is necessary to determine whether they are benign... or whether they ... foster harmful and divisive stereotypes without a compelling justification."); Adarand Constructors, Inc. v. Pena, 515 U.S. 200, 241 (1995) (Thomas, J., concurring) ("'[R]acial paternalism and its unintended consequences can be as poisonous and pernicious as any other form of discrimination. Socalled 'benign' discrimination teaches many that because of chronic and apparently immutable handicaps, minorities cannot compete with them without their patronizing indulgence."); Fullilove v. Klutznick, 448 U.S. 448, 545 (1980) (Stevens, J., dissenting) (" $[E] v e n$ though it is not the actual predicate for this legislation, a statute of this kind inevitably is perceived by many as resting on an assumption that those who are granted this special preference are less qualified."), quoted with approval in Adarand, 515 U.S. at 229. 
Adarand decision, "[t]he application of strict scrutiny ... determines whether a compelling governmental interest justifies" the "injury" that affirmative action plans inflict. ${ }^{39}$

The other way to understand narrow-tailoring tests is to see them as a device for smoking out impermissible purposes. ${ }^{40}$ The Court itself used to describe strict equal protection scrutiny this way. In 1989, the Court said that strict scrutiny had to be applied to racial classifications in order to "smoke out" those classifications that were "in fact motivated by illegitimate notions of racial inferiority" or "prejudice."41

But in order to rationalize striking down all affirmative action plans under strict scrutiny, the Court was compelled to turn away from this smoking-out conception. For none of the justices has ever claimed that a typical affirmative action program's failure to satisfy strict scrutiny demonstrates that the program was "in fact motivated by notions of racial inferiority." Rather, the Court's present reasoning, as described a moment ago, is and has to be that strict scrutiny is a balancing test, and that an affirmative action plan should be subjected to strict scrutiny to see whether its inadvertent or unintended consequences are justified by sufficiently weighty interests (which, in the Court's judgment, it turns out, they almost never are).

So we have two ways of understanding narrow-tailoring tests, and it makes a good deal of difference which one we choose.

In the First Amendment context, this choice is visible in the $O^{\prime} B r i e n$ problem discussed earlier. The $O^{\prime} B r i e n$ test runs into trouble with simple cases like A's because it presents itself as a balancing test, unmoored from an inquiry into legislative purpose. Viewed this way, $O$ 'Brien's prongs become unhinged, and its inquiry into how well a law furthers important governmental interests becomes nothing more than superlegislative judicial review of the law's policy merits, leading straight to the $O^{\prime} B$ rien-as-Lochner result.

But if the $O^{\prime} B r i e n$ test is understood as a smoking-out device, triggered only upon strong suspicion of an impermissible, speech-suppressing purpose, then an examination of how well a law furthers the state's putatively speechneutral interests makes good sense. A flag-burning law, defended as a fire safety measure, would properly trigger $O^{\prime} B$ rien review and would never satisfy such review. (Does the burning of flags really pose significant fire hazards? Even if it does, why is the burning of flags singled out for prohibition?) First Amendment doctrine has to decide whether to read $O^{\prime}$ Brien as a balancing test

39. Adarand, 515 U.S. at 230 (emphasis added).

40. For a detailed discussion in the equal protection context, see Jed Rubenfeld, Affirmative Action, 107 YALE L.J. 427, 436-43 (1997). For an excellent discussion making a similar point in the free speech context, see Kagan, supra note 20, at 453-56.

41. City of Richmond v. J.A. Croson Co., 488 U.S. 469, 493 (1989) (plurality opinion). 
or a smoking-out device. Only when understood in the latter's purposive terms does the $O$ 'Brien test make sense.

In actuality, $O^{\prime} B r i e n$ has by and large played its proper, purposive function in First Amendment law. Courts do not, under O'Brien, get themselves entangled in superlegislative review of speed limits or other generally applicable conduct laws. O'Brien is applied with bite only when there exists a significant, plausible suspicion of an improper speech-suppressing purposeand thus only when failure to satisfy $O^{\prime} B r i e n$ plausibly implies the existence of an impermissible purpose. ${ }^{42}$

When this line of thought is worked through-when the purposivism instinct in First Amendment law is taken seriously - a profound rethinking of a number of First Amendment issues becomes possible. In a little while, I will give some concrete examples. But first: assuming that the purposivist and balancing approaches to First Amendment law do generate different answers, I need to say something more about why purposivism's answers should be preferred.

\section{The Costs of Balancing, the Benefits of Purposivism}

A warning: The five reasons I am about to give do not purport to answer the "big why"- the why that would be put on the table if someone concerned with the First Amendment's philosophical foundations demanded to know what the ultimate normative-constitutional justification would be for a purposivist freedom of speech. The reasons I am about to offer work at a lower level of analysis. They explain why free speech purposivism is preferable to balancing without invoking any grand theory of the First Amendment and without relying, therefore, on the large but necessarily contestable propositions about the First Amendment's ultimate purpose that such a theory alone could deliver. In Part IV, I return to the questions of First Amendment theory here deferred.

1. The first reason is a reminder. Purposivism yields straightforward answers to the simple but basic problems with which this article began. For example, it makes A's and B's cases easy in just the way they ought to be easy. Balancing cannot do so.

In A's case, if balancing were taken seriously, judges would have to try to measure the value of driving at high speed as an expressive activity, then balance this value against the pertinent harms, and then ask whether the state could successfully address these harms while letting some or all people drive a little faster on some or all highways at some or all times. In B's case, a judge

42. See Kagan, supra note 20, at 491-505; see also Robert Post, Recuperating First Amendment Doctrine, 47 STAN. L. REv. 1249, 1256 (1995) ("[A] close analysis of these cases indicates that they almost invariably tum on judicial scrutiny of the purposes served by the regulation at issue."). 
would have to decide whether the expressive value of the shirt in question outweighs all the costs that the state might say are caused thereby. Perhaps the protest is demoralizing the police and increasing popular resistance to legitimate police practices. Or perhaps the state will argue that, even though the city's ordinance was not enacted for traffic purposes, the shirt is so distracting that it causes an accident every now and then. Do these costs outweigh the shirt's expressive benefits? How is a judge to make this calculation?

By contrast, purposivism resolves these cases in clear, straightforward fashion. Because A's contention (that a higher speed limit would have been safer and more fuel efficient) does not allege that he was punished for speaking, his suit is dismissed for failure to state a claim. Because B was jailed for having a protest message on his shirt, $B$ wins. Period.

Moreover, purposivism solves the Spence problems discussed above-for example, the problems associated with art. (What works count as art, and why is art protected despite its failure to satisfy Spence?) It is not that purposivism provides conclusive definitions of expressive conduct or art. Rather, purposivism obviates the need for such definitions.

Say that the mayor of New York bans an execrable painting of the Virgin for casting aspersions on a religious figure whom many New Yorkers hold sacred. Under Spence, a judge would have to determine whether the painting successfully conveys a particularized message-meaning that there would be no First Amendment protection if, for example, most viewers of the painting left the museum utterly perplexed about its meaning. And if instead a judge were to say that art occupies a special status, entitled to First Amendment protection without satisfying Spence, the difficulties become still worse, for now the judge must decide whether the painting is art. (This is the problem that Posner correctly identifies when he speaks of judges "play[ing] art critic."43) A purposivist First Amendment jurisprudence cuts through all these difficulties. Whether the painting qualifies as expressive conduct or as art is irrelevant. The state's purpose is dispositive, and where the state has banned a work because that work is said to communicate a view or attitude offensive to people of certain religious beliefs, the ban is unconstitutional.

2. The intelligibility of balancing in First Amendment law is hardly perspicuous. Nothing can be balanced against anything else without a common unit of measure. What is the unit of measure when First Amendment rights are "weighed" against governmental interests? No court has ever said.

The debate over balancing in free speech jurisprudence and elsewhere in constitutional law is an old story. ${ }^{44}$ But it is worth the attention it gets. I am

43. See note 26 supra.

44. See, e.g., Ely, supra note 33; Fallon, supra note 37, at 78-83; Robert B. McKay, The Preference for Freedom, 34 N.Y.U. L. REv. 1182, 1182-84, 1194-95 (1959) (discussing 
not arguing here against all balancing or all cost-benefit reasoning, which is obviously not unintelligible as such, and which might possibly be appropriate even in some constitutional settings. But at least in First Amendment controversies, the language of balancing betrays a strange unreality.

Someone says that the First Amendment "interests" associated with pornography are "outweighed" by the resultant violence to and subordination of women. Someone else replies that on the contrary, as far as he is concerned, the First Amendment rights at stake outweigh the harms. Neither of these people will actually be engaged in anything like a real balancing of interests. They will be wholly unable to explain the "calculations" that supposedly went into their "balance." Neither will have the slightest actual idea of the realworld amounts of the "costs" or "benefits" involved, nor of how to measure them, nor even of what would count as a relevant cost or benefit. How then did they know which way, for them, the balance came out? The rhetoric of balancing is a disguise in such contexts. It serves as a conclusory, obfuscatory language masking more fundamental, although frequently very poorly thoughtthrough instincts about the freedom of speech.

The confusions produced by the balancing-test approach to free speech are most visible in cases of incitement. Suppose that a movie about race relations in America proves to induce a few people to commit acts of violence on leaving the theater. As a result, a state bans the movie. Everyone understands that such a ban would be unconstitutional. What will the balancer say about this? He will say that the expressive value of the movie outweighs the harms. But how does he know? Has he measured the harms? Maybe one or two people will actually die in the fighting spurred by the movie. Does the balancer have some metric that allows him to say that the movie's expressive value is worth one or two deaths?

Now suppose that I deliberately incite an impassioned crowd and the circumstances are such that violence is likely to ensue. Here, the balancer will probably say that there is no constitutional protection. His ostensible reason will be that my speech might induce some people to commit acts of violence. Maybe one or two people will actually die. But why does the balance now tip against speech? The harms here seem to be of the same kind and magnitude as those caused by the inflammatory movie. The balancer will evidently have to say that the movie had greater First Amendment value than did my speech before the impassioned crowd. But how does he know that?

The balancer is not balancing at all in these cases. He thinks he is. But no matter how confidently and naturally he describes his conclusions as a product

the extent of the "preferred position" of the First Amendment); Frederick Schauer, Commensurability and Its Constitutional Consequences, 45 HASTINGS L.J. 785, 786-803 (1994) (offering some defense against the notion that costs and benefits almost never reduce to a single metric). 
of a balancing of interests, these conclusions actually reflect more categorical judgments about what the First Amendment does and does not protect. Balancing cannot explain these judgments; purposivism can. ${ }^{45}$

3. Cost-benefit thinking offers an untenable account of strict scrutiny and other forms of heightened review. In fact, cost-benefit thinking may make strict scrutiny the first doctrine in American constitutional history to be unconstitutional under itself.

Consider, for example, strict scrutiny of affirmative action. As observed earlier, the Court today defends this result on explicit cost-benefit grounds: The racial classifications used in affirmative action plans threaten such serious, albeit inadvertent racial harms-especially the fostering of invidious stereotypes of racial inferiority-that they can be permitted only where compellingly justified. But if this is the reason why strict scrutiny applies, then we are entitled to ask why the Court does not apply strict scrutiny to other state actions, which, although racially neutral, also inadvertently foster stereotypes of racial inferiority.

Standardized tests notoriously promote invidious racial stereotypes. To whatever extent affirmative action has promoted stereotypes of racial inferiority (among those inclined to believe such things), there can be little doubt that standardized tests have done the same thing - almost certainly to a greater degree. The singling out of racial classifications for strict scrutiny, if defended in the cost-benefit fashion just described, turns out to be substantially underbroad and overbroad. It leaves untouched many state actions that, like the use of standardized tests, cause the very same harm to the same or to an even greater extent. Which is to say that strict scrutiny, so defended, fails strict scrutiny. ${ }^{46}$

This problem has a corollary in First Amendment doctrine. We observed it a moment ago. When explained in cost-benefit terms, the fact that a person can be constitutionally punished for incitement indicates that, under strict scrutiny, speech loses its protection if it is likely to bring about unlawful acts of violence. But then why can't a state ban a movie known to lead to similar unlawful acts of violence? Why can't a state ban pornography upon a probabilistic showing that pornography increases the incidence of rape? ${ }^{47}$

Viewed as a species of cost-benefit analysis, the First Amendment's

45. For an explanation of how purposivism solves the problem of incitement to riot, see Part IV infra.

46. For more on this point, see Rubenfeld, supra note 40, at 449-52.

47. See, e.g., Am. Booksellers Ass'n v. Hudnut, 771 F.2d 323, 329 (7th Cir. 1985) (striking down an antipornography ordinance despite assuming arguendo that "[d]epictions of subordination tend to perpetuate subordination" and that the "subordinate status of women in turn leads to affront and lower pay at work, insult and injury at home, battery and rape on the streets"), aff'd mem., 475 U.S. 1001 (1986). 
narrow-tailoring tests make no sense. The $O^{\prime} B r i e n$ test becomes a reprise of Lochner v. New York. First Amendment doctrine as a whole becomes inexplicable-in one context treating certain harms as constitutionally dispositive, but elsewhere ignoring equal or greater harms of the very same kind. In other words, when defended in cost-benefit terms, free speech strict scrutiny, like equal protection strict scrutiny, is not narrowly tailored to achieve its own putative objectives. Only purposivism, viewing narrow-tailoring tests as smoking-out devices, restores coherence to heightened scrutiny.

4. Free speech balancing, if taken seriously, would make every application of every antidiscrimination statute into a serious First Amendment problem. This point takes a little explaining.

A cost-benefit approach to free speech could claim one considerable virtue lacking in a purposivist approach. A balancing judge could invalidate a law on the ground that, whatever its purpose may have been, the law in fact has a significant, disparate, adverse impact on the communication of disfavored political positions. For example, banning draft card burning in 1968 obviously had a disparate impact on those protesting the Vietnam War. A balancing judge could in principle strike down the law on this basis, regardless of whether the law's purpose had anything to do with speech. Thus cost-benefit analysis could claim to protect the First Amendment playing field in a way that purposivism cannot.

But this seeming virtue, if practiced sincerely, would be a vice. The statutes in our legal system with the most obvious and most profound adverse impact on the expression of a politically disfavored viewpoint are discrimination statutes. Discrimination is highly expressive. Antidiscrimination laws directly prevent people from engaging in what is probably the most powerful, most effective means of communicating messages of group inferiority and superiority. And make no mistake: The speech impact of antidiscrimination laws is manifestly biased. Discrimination laws permit people, for example, to use hiring decisions to express viewpoints associated with sexual and racial equality, while forbidding people to use hiring decisions to express sexist or racist viewpoints.

A balancer will presumably respond that this disparate speech impact is no problem because in this context compelling governmental interests justify the First Amendment burdens. But at a minimum, a balancer will have to be prepared to grant exemptions. He will have to stand ready to entertain an infinite number of as-applied challenges. $\mathrm{He}$ will have to recognize a constitutional right to discriminate whenever parties can show that discrimination laws have a particularly severe effect on their speech interests and that an exception could be carved out for them without undue cost. There is nothing speculative about this scenario. It precisely describes the recently decided case of Boy Scouts of America v. Dale, where on cost-benefit grounds the Supreme Court held, for the first time, that the freedom of expression 
conferred on a party a constitutional right to discriminate. ${ }^{48}$ Boy Scouts, discussed in more detail below, makes perfect sense in the language of First Amendment balancing. If this language were really taken seriously, Boy Scouts should be only the first of many free speech exemptions from antidiscrimination statutes. ${ }^{49}$

5. Finally, and most fundamentally, the balancing-of-interests view of free speech should be rejected because it cannot be squared with the First Amendment's foundational paradigm cases. By the foundational paradigm cases, I mean the kind of laws that the freedom of speech at its historical core categorically forbids.

For example, if it means anything, the First Amendment means that Congress may not censor or apply seditious libel laws to political dissenteven where such dissent could genuinely lead to violence, as was obviously the case in late eighteenth-century America ${ }^{50}$ From a balancing perspective, there is no intellectually honest way to explain such categorical rules. Everything should be much more dependent on circumstances. Even assuming that a balancer could coherently demand "strict scrutiny" of prior restraints or seditious libel laws, there is no a priori reason to suppose that these measures would not be found justified, precisely and especially in the kind of turbulent political conditions that characteristically cause governments to enact them.

Indeed one of the virtues of a prior restraint is that it can be very narrowly tailored: The censor of a newspaper might carefully expunge only those passages containing blatant criticism of certain government policies. If the narrow-tailoring inquiry is understood as part of a cost-benefit balancing test, this feature of prior restraints will perversely make them seem more constitutionally attractive, ceteris paribus, not less so. A prior restraint might well be the most narrowly tailored possible means of achieving the government's objectives. From a cost-benefit perspective, it should seem rather strange that First Amendment doctrine treats prior restraints as paradigmatic violations.

By contrast, if the narrow-tailoring inquiry is understood in purposivist terms, it will immediately be seen that the kind of narrow tailoring offered by a prior restraint is what makes the restraint not merely less constitutionally attractive, but categorically unconstitutional. The fact that a prior restraint is narrowly tailored to expunge only blatant passages of political dissent demonstrates that the state's purpose was, precisely, to target political dissent.

48. 120 S. Ct. $2446(2000)$.

49. Someone might object that discrimination statutes are also problematic from a purposivist point of view. For this objection, and the answer to it, see Part III.C infra.

50. See, e.g., Near v. Minnesota, 283 U.S. 697 (1931) (striking down application of nuisance law to publications charging law enforcement officials with corruption and neglect of duty). For more on paradigm case interpretation, see Part IV.A \& note 117 infra. 
Next case.

Cost-benefit constitutional analysis cannot generate categorical rules. That is why so many people favor such analysis. Any result is in principle derivable from a balancing test. Everything will depend on the relevant costs and benefits, the indeterminacy of which will allow anyone to arrive at any position he or she desires. The truth is that no one can pretend to know whether the freedom of speech itself is worth its costs, which might conceivably be, someday, a complete breakdown in social order.

A cost-benefit version of strict scrutiny could easily justify censoring political criticism in circumstances of substantial political turbulence. The only way for a balancer to avoid this conclusion is by assigning infinite or near infinite positive value to political dissent, in which case he would not really be engaged in balancing at all. Unless it is artificially weighted this way, a costbenefit approach to the First Amendment cannot generate categorical answers consistent with the paradigm cases. Purposivism can.

\section{The Concept of State Purpose}

The problem with purposivism, of course, is that governmental purposes are difficult to ascertain. Indeed, it might be said that the entire idea of a multimember legislature having "a purpose" is a figment of the imagination. Different legislators typically have very different motives. There may be Condorcet intransitivities in the legislators' aggregated preferences. And so on.

I do not intend to try to lay out here a comprehensive theory of legislative purpose. But to address these objections and to avoid misunderstandings, I need to say a few words. To begin with, it is worth remembering that American courts inquire into legislative purpose every day. Doing so is a canonical element-arguably the defining element-of statutory interpretation. To be sure, this response may remind people of the priest who, when asked if he believed in baptism, replied, "Of course-I've seen it done." But the mysteriousness of legislative purpose is overrated.

For example, a law can fully disclose on its face the purpose relevant to First Amendment analysis. Say that Richard Posner writes a book asserting that the President of the United States committed crimes and then told "gaudy" lies to cover them up. Say that Posner is arrested under a law that criminalizes the publication of any book tending to bring the President or his administration into disrepute. The speech-targeting purpose of this law is apparent on its face. No further inquiry into legislative purpose is necessary. Of course such a law would not be found any longer in the United States. But that is the point. Everyone understands the unconstitutionality of a law manifestly targeting political criticism.

The illustration is also important for another reason: It shows that the 
concept of purpose, as I use the term, is different from that of "motive." By a legislator's "motive," I mean the ultimate or further purposes on the basis of which a legislator may cast his vote. Imagine that every legislator who voted for the law criminalizing Posner's book was genuinely motivated solely by a concern that readers might be induced to perpetrate terrorist attacks on federal buildings. Does this mean that the law was constitutional after all, because its true target was conduct rather than speech?

No. The legislators' motives in such a case are irrelevant. The law still purposefully targets speech, and Posner is still unquestionably punished for speaking. That the legislators targeted speech with the further purpose of preventing illegal conduct makes no difference. In other words, the existence of a nonspeech-related, constitutionally legitimate motive (or further purpose) does not cure an unconstitutional immediate purpose..$^{51}$

The more serious difficulties in determining state purpose arise when someone claims the existence of an impermissible purpose that does not appear on the face of the governmental action. In the First Amendment context, this might happen in two different kinds of cases. First, state executive officers (such as policemen) might be said to have targeted speech while acting under color of a speech-neutral law. Second, the true purpose behind a law might be said to be the punishment of speech even though the law appears speechneutral on its face.

In the first kind of case, hard factual questions may be presented, but determining a police officer's purposes raises (at least in principle) no difficulties greater than those present whenever the law deals with problems of individuals' intentions, as it does in numerous contexts. If police routinely ignore a law against jaywalking, but suddenly arrest every jaywalker who happens to be carrying a protest sign, there is good reason to believe that the police are in fact punishing people for speaking. It is only, therefore, the second kind of case-in which plaintiffs claim that the true purpose of a facially neutral law is to target protected speech-that raises special difficulties.

And here the judiciary has a familiar set of tools at hand. Relevant evidence will include the law's language, its effects, its legislative history, the circumstances surrounding its enactment, and common knowledge. In some cases, this evidence might be sufficient in itself to allow a court to find an unconstitutional purpose. In others, such evidence will not prove unconstitutional purpose but will raise a strong suspicion thereof. In the latter circumstance, the well-understood judicial response is to apply a narrowtailoring test exactly as described above: as a smoking-out device, evaluating whether the terms of the law genuinely fit the asserted speech-neutral purposes.

51. For more on this point, in the context of equal protection law, see Jed Rubenfeld, The Purpose of Purpose Analysis, 107 YALE L.J. 2685 (1998). 
If the law turns out to be substantially or illogically overbroad or underbroad with respect to these putative legitimate purposes, a court is entitled to conclude that these purposes are not in fact the law's true object.

There is nothing new in any of this. Over one hundred years ago, Justice Field, riding circuit, heard a case challenging on Fourteenth Amendment grounds a San Francisco law requiring the hair of every male prisoner at the county jail to be "cut or clipped to an uniform length of one inch from the scalp."s2 Justice Field struck down the law. His opinion is worth quoting at length. Justice Field first observed a conspicuous overbreadth and underbreadth that belied San Francisco's attempt to defend its ordinance as a sanitation or health measure:

The cutting off the hair of every male person within an inch of his scalp, on his arrival at the jail, was not intended and cannot be maintained as a ... sanitary regulation. The act ... can only be a measure of health in exceptional cases. Had the ordinance contemplated a mere sanitary regulation it would have been limited to such cases and made applicable to females as well as to males, and to persons awaiting trial as well as to persons under conviction..$^{53}$

Field's conclusion: "The claim... put forth that the measure was prescribed as one of health" was "a mere pretense." 54 But a pretense for what? The opinion continues: "The ordinance was intended only for the Chinese in San Francisco. This was avowed by the supervisors on its passage, and was so understood by every one. The ordinance is known in the community as the 'Queue Ordinance' ...."."55

It appears that many Chinese immigrants were, like plaintiff Ho Ah Kow, "caught" lodging in rooms of less than five hundred cubic feet, the penalty for which (under a separate California criminal statute) was a fine of up to fifty dollars or, if the offender would not pay, incarceration for five days..$^{56}$ Evidently the "Queue Ordinance" was enacted to induce the Chinese to pay rather than go to jail:

The reason advanced for its adoption ... is, that only the dread of the loss of his queue will induce a Chinaman to pay his fine.... Probably... the thumbscrew, or the rack, would accomplish the same end; and no doubt the Chinaman would prefer either of these modes of torture to that which entails upon him disgrace among his countrymen and carries with it the constant dread of misfortune and suffering after death....

... The statements of supervisors in debate on the passage of the ordinance cannot, it is true, be resorted to for the purpose of explaining the meaning of the terms used; but they can be resorted to for the purpose of ascertaining the

52. Ho Ah Kow v. Nunan, 12 F.Cas. 252, 253 (C.C.D. Cal. 1879) (No. 6,546).

53. Id. at 254 .

54. Id.

55. Id. at 255 .

56. Id. at 254 . 
general object of the legislation proposed, and the mischiefs sought to be remedied. Besides, we cannot shut our eyes to matters of public notoriety and general cognizance. When we take our seats on the bench we are not struck with blindness, and forbidden to know as judges what we see as men . . .57

It made no difference that the ordinance was drafted in general terms. Its purpose rendered it unconstitutional. This was a principle extending well beyond the Queue Ordinance-a principle extending, in fact, to protections afforded by the First Amendment:

We have, for instance, in our community a large number of Jews. They are a highly intellectual race, and are generally obedient .... But, as is well known, they have peculiar opinions with respect to the use of certain articles of food .... Now, ... an ordinance of the supervisors requiring that all prisoners confined in the county jail should be fed on pork would be seen by every one to be leveled at them; and, notwithstanding its general terms, would be regarded as a special law in its purpose and operation.

During various periods of English history, legislation, general in its character, has often been enacted with the avowed purpose of imposing special burdens and restrictions upon Catholics; but that legislation has since been regarded as not less odious and obnoxious ... than if the persons at whom it was aimed had been particularly designated..$^{58}$

Ho Ah Kow demonstrates many of the familiar tools available to judges in assessing claims of impermissible legislative purpose. Ultimately, however, judicial determinations of legislative purpose must be recognized for what they often are-legal constructions, as opposed to determinations of the actual, "subjective" intentions of the legislators. The purpose that judges are looking for is the purpose that constitutional law should regard as the legislation's purpose - the purpose that should be imputed to the legislation.

The construction of a law's true purpose can be difficult. When there are sufficient indicia of a suspect purpose, the way for judges to operationalize the task is, as just described, through the use of heightened, narrow-tailoring review, testing whether a suspect law can really be explained in terms of the legitimate purposes that the state will invariably claim for it. Such heightened review can properly result in a determination of impermissible purpose even when many or most of the legislators had no such purpose-or when they had such a purpose, but only unconsciously. One way to think of the judicial inquiry is to ask what a reasonable citizen under the actual circumstances would have understood the law's purpose to be. San Francisco citizens understood the real purpose of the Queue Ordinance, and their understanding could still be counted as correct even if it turned out that every one of the San Francisco supervisors had simply been paid off to vote for the ordinance,

57. Id. at 255 .

58. Id. at 255-56. 
without even knowing what the ordinance said.

Heightened narrow-tailoring review is inappropriate for most legislation. If the judiciary began subjecting most legislation to narrow-tailoring tests, most legislation would be struck down, because most legislation really is substantially overbroad, underbroad, or arbitrary with respect to the objects being pursued.

Speed limits provide a good example. A fifty-five mile-per-hour speed limit is a blunderbuss law. Some drivers are just as safe at higher speeds, some are just as unsafe at fifty, and in any event drawing the line at fifty-five is necessarily arbitrary. In other words, a speed limit almost certainly could not pass muster if it were subjected to "strict scrutiny." But a speed limit is not for that reason unconstitutional. Heightened scrutiny does not apply to a speed limit. Why not? Because there is no reason to think that a speed limit's failure to satisfy heightened means-ends scrutiny shows that it was enacted for impermissible purposes. Narrow-tailoring review is appropriate only where other evidence has already established a strong suspicion of impermissible purpose, so that the judiciary becomes entitled to examine skeptically whether the law at issue can really be explained by reference to the putative, legitimate interests claimed for it.

This is the correct justification for the well-known "presumption of constitutionality" that seems to pop up without rhyme or reason in and out of First and Fourteenth Amendment jurisprudence. The presumption means just this: The judiciary will not ordinarily suppose that legislators acted in pursuit of an unconstitutional purpose. Thus where the challenge to a law goes to its purpose-as it properly does in First and Fourteenth Amendment cases-most laws should be subject to the most tolerant level of review (so-called rational basis review). But if a strong suspicion of impermissible purpose can be raised, then heightened scrutiny becomes appropriate. The result, however, is that there will inevitably be occasions on which laws are upheld even though, in reality, they were enacted for constitutionally impermissible purposes.

In other words, some unconstitutionalities will slip through undetected. Is that a reason to oppose purposivism? No, although it might be a reason to demand, in certain kinds of cases, a relaxation of the presumption of constitutionality just described. Every constitutional doctrine entails the risk of false negatives. Balancing tests, to the extent that such tests are intelligible at all, are obviously subject to empirical error. Judges purporting to balance constitutional rights against state interests might easily miscalculate the pertinent costs and benefits.

\section{PRACTICAL IMPLICATIONS: THREE ILLUSTRATIONS}

To make state purposes central to the First Amendment is not, without 
more, to say very much about the actual content of free speech law. Purposivism obviously requires an account of what purposes the First Amendment does and does not permit. For after all, there can be little doubt that people may be punished for some kinds of speech-for libel, say, or for perjury, or for approaching a bank teller and saying, "Your money or your life." A good deal of speech is unprotected, and a comprehensive purposivist theory of the First Amendment would have to address this fact. Part IV returns to this problem.

In this Part, however, I have a much more limited goal: to highlight a few clear illustrations of First Amendment purposivism. Accordingly, I will proceed on the basis of a modest, hopefully straightforward, but hopefully useful working hypothesis. The hypothesis is this: If the purpose behind a law is to punish people for engaging in protected speech, the state is acting unconstitutionally.

For purposes of this discussion, "protected speech" means any speech that courts say is constitutionally protected (as, for example, political dissent is, but libel is not). By punishing people "for engaging" in protected speech, I mean, once again, that the law punishes people because of the communicative harms allegedly entailed by such speech. A person is not punished for engaging in speech if he is punished merely as a result of engaging in speech (ordinary tax laws do not punish for speaking even when they apply to persons who refuse to pay their taxes as an expression of political protest). Nor is a person punished for engaging in protected speech if, say, his speech is subjected to a generally applicable noise limitation. Finally, this discussion is not intended to apply to the special contexts of government-owned property (for example, military bases) where the full set of ordinary First Amendment protections does not apply.

With this working hypothesis, I will try to show that purposivism yields determinate results for three controversial First Amendment issues. I know: Readers will think it must be circular or obvious to say that a state cannot deliberately act to suppress "protected" speech. Perhaps so; but read on.

\section{A. Begging}

Two years ago, in Smith v. City of Fort Lauderdale, ${ }^{59}$ the United States Court of Appeals for the Eleventh Circuit had to decide the constitutionality of an antibegging ordinance. Fort Lauderdale had banned begging on its main five-mile strip of public beach as well as on the contiguous commercial promenade (the "beach area"). Plaintiffs, a "class of homeless people,"

59. 177 F.3d 954 (11th Cir.), cert. denied, 120 S. Ct. 402 (1999). 
claimed that the ordinance violated the First Amendment. ${ }^{60}$

As the Eleventh Circuit was aware, a decade-old Second Circuit decision had suggested that begging might not count as protected speech at all, but rather as mere conduct, for First Amendment purposes. ${ }^{61}$ The Eleventh Circuit firmly rejected this suggestion. "As an initial matter, we note that ... begging is speech entitled to First Amendment protection." 62 The court also observed that the Fort Lauderdale "beach area" was a public forum for First Amendment purposes. ${ }^{63}$ Nevertheless, the court upheld the ordinance.

The Eleventh Circuit analyzed Fort Lauderdale's ordinance under the "time, place, and manner" test. ${ }^{64}$ Finding that "the City's interest in providing a safe, pleasant environment and eliminating nuisance activity on the beach" easily qualified as a "significant government interest," the court went on:

The City has ... determin[ed] that begging in [the] beach area adversely impacts tourism. Without second-guessing that judgment, which lies well within the City's discretion, we cannot conclude that banning begging in this limited beach area burdens 'substantially more speech than is necessary to further the government's legitimate interest.' ... [The] suppression of begging in the Fort Lauderdale Beach area is materially mitigated by the allowance of begging in streets, on sidewalks, and in many other public fora throughout the City. ${ }^{65}$

In other words, the city's interest in tourist dollars outweighed the beggars' First Amendment freedoms, especially considering that begging was permitted elsewhere in town.

From a cost-benefit perspective, the city's determination and the Eleventh Circuit's decision are not unreasonable. Vacationers probably hate it when poor or putatively poor people ask them for charity. But from a purposivist perspective, this decision, which the Supreme Court declined to review, is pretty much a travesty. Fort Lauderdale's manifest purpose was to target certain speech acts-namely, requests for alms-qua speech acts. The city's ordinance manifestly (facially) punishes people for speaking. It makes criminal liability turn on whether a person has spoken certain words or otherwise communicated a request for charity. Everyone would see this if Fort

60. Id. at 955 .

61. "Whether with or without words, the object of begging and panhandling is the transfer of money. Speech simply is not inherent to the act; it is not of the essence of the conduct." Young v. New York City Transit Auth., 903 F.2d 146, 154 (2d Cir. 1990) (Altimari, J.). This is like saying: "Whether with or without words, the object of electoral advertising is the accumulation of votes. Speech simply is not inherent to the act; it is not of the essence of the conduct."

62. Smith, 177 F.3d at 956 .

63. Id.

64. Id.

65. Id. at 956-57 (citations omitted) (quoting Ward v. Rock Against Racism, 491 U.S. $781,789(1989))$. 
Lauderdale had prohibited soliciting votes rather than soliciting alms.

If the Eleventh Circuit had ruled that begging was unprotected speech, the issues raised by the decision would have been different. But the court expressly conceded that begging "is speech protected by the First Amendment." 66 This means that Fort Lauderdale's ordinance should have been deemed unconstitutional period. The city deliberately targeted protected speech due to harms supposedly flowing from that speech. A person convicted under this ordinance will be punished for-his crime will consist of-asking $a$ question. There could be no clearer violation of the First Amendment.

The reason why the Eleventh Circuit did not see things this way is that the court essentially understood First Amendment rights within the framework of a (quite deferential) balancing test. From a balancing perspective, it is perfectly sensible to say that the loss in tourist dollars caused by beachfront begging outweighs the First Amendment interests at stake. (It is also perfectly sensible to say the opposite. It is perfectly sensible to come to any conclusion at the end of a First Amendment balancing test.) But once again, we would see at once the absolute indefensibility of this result if Fort Lauderdale had banned soliciting votes, rather than alms, in the beach area. We would not, I think, for a moment accept the idea of a balancing of interests in such a case. Does the First Amendment permit a city to decide that tourist dollars are worth more than political advocacy in the city's parks or other public places?

This question will not throw a balancer off-balance. He will say that begging is just not as "weighty," for First Amendment purposes, as "political speech." Political speech, he will say, has the highest First Amendment value; begging has a much lower value. Political speech is therefore insulated from the ordinary cost-benefit calculations that lawmakers might engage in; begging is not. I suppose, then, for clarity, I should emphasize two different points. First, purposivism will differ from a balancing-test approach in just this sort of case, because purposivism rejects the entire apparatus of First Amendment balancing, including any "high-value/low-value" distinctions among different "categories" of protected speech. Second, purposivism is right to reject this high-value/low-value balancing-test approach, which is totally unacceptable.

I will say more about the high-value/low-value approach to speech below. But for now just consider: Could Fort Lauderdale constitutionally ban people from publicly criticizing the weather? Or could Boston ban people in the town green from criticizing the Babe Ruth trade? I hope and believe that American courts would answer these questions in the negative. But why? The reason cannot be that the harmfulness of such speech is obviously less than that of begging. Perhaps the very mention of Babe Ruth gets Bostonians so riled up that an occasional fight breaks out, which would be bad for tourism, among

66. Id. at 956 . 
other things. A balancer would at least have to try to measure these potential harms before he could possibly know what to think. For surely it will not be said that "weather speech" or "sports speech" is of such high First Amendment value that, like "political speech," but unlike nasty, miserable begging, it is insulated against ordinary cost-benefit judgments.

A lot of scholarly and judicial language suggests that "political speech" is the true core of the First Amendment and that words moving away from this core are entitled to proportionately less constitutional protection. But the notion that judges could successfully tell us what speech is "political" and what is not should be welcomed with the same enthusiasm as the notion that judges could successfully tell us what speech is "art" and what is not. Begging, for example, is political speech-from a certain, perfectly plausible point of view sounding in political theory, sociology, and so on. Do we really want judges passing on the soundness of this point of view? And do we really want a judge to be able to hold that "weather speech" or "sports speech" is not political and therefore is not of much First Amendment importance, so that Fort Lauderdale could arrest people on the beach for complaining about the clouds, and Boston could arrest a New Yorker for boasting about the Babe? The whole highvalue/low-value balancing-test approach to the First Amendment, familiar as it is, and necessary as it is to support cases such as Smith v. City of Fort Lauderdale, is unacceptable.

If Fort Lauderdale cannot arrest people on the beach for soliciting votes or for criticizing the weather, it should not be able to arrest them for soliciting alms. To be sure, one would have to have a heart of stone not to find beggars unpleasant, but the analysis does not change because of that fact. Fort Lauderdale's manifest purpose was to stop protected speech due to harms said to result from people hearing that speech. (Or to put the same point in the language of current doctrine, Fort Lauderdale's ordinance should plainly have been regarded as content-based, so that it could not have been upheld as a valid "time, place, and manner" regulation.) In a purposivist First Amendment jurisprudence, Smith would have been an easy case. Fort Lauderdale's ordinance punished persons for engaging in protected speech and hence should have been deemed unconstitutional-period.

\section{B. Campaign Finance Regulation}

Buckley v. Valeo ${ }^{67}$ notoriously struck down campaign expenditure caps that Congress had enacted in the early 1970s, while upholding Congress's contribution limits. I do not propose to undertake here a thorough examination of Buckley or of campaign finance regulation. But it seems worth pointing out

67. 424 U.S. 1 (1976). 
that, for better or worse, according to the analysis laid out so far, the much maligned Buckley decision was correct-in both its principal holdings.

I cited Buckley earlier for its highly typical balancing-test rhetoric. ${ }^{68}$ (The government's interest in combating corruption, the Buckley Court said, was "weighty" enough to "justify" the contribution limitations, but "inadequate to justify" the expenditure limitations. ${ }^{69}$ ) Buckley is also typical, however, for having actually arrived at its conclusions not through a balancing test, but through a narrow-tailoring analysis conforming quite closely to the kind of First Amendment purposivism I have described.

Consider the Court's analysis of the cap on "independent expenditures," which covered, as the Court interpreted it, spending only on "communications that include[d] explicit words of advocacy of election or defeat of a candidate" effected without "prearrangement or coordination ... with the candidate or his agent[s]."70 Congress had limited such expenditures, with respect to any clearly identified candidate, to $\$ 1,000$ per year per person. When viewed as an anticorruption measure, the Court found, this independent expenditure cap was fatally underinclusive and overinclusive. On the one hand, those "desiring to buy influence" could easily avoid the cap by spending "as much as they want" on communications that did not engage in "express advocacy." 11 On the other hand, "[ $t$ ]he absence of prearrangement" made it less likely that most independent expenditures "will be given as a quid pro quo."72

Superficially, these formulations give the impression that the Court was engaging in judicial superlegislative review of how well Congress had done its job-of how well the statute that Congress passed would further the anticorruption objective that Congress meant to be pursuing. When Buckley's reasoning is looked at this way, a natural and very powerful response is to point out that Supreme Court justices are utterly, almost uniquely, incompetent to decide what measures are needed to avoid campaign finance corruption. Thanks to the Court's intervention, Buckley left the nation with a loopholeridden campaign finance regulatory scheme that no rational legislature would ever have enacted (because the contribution and expenditure limits made sense only in tandem). ${ }^{73}$ Indeed, any judicially managed scheme of campaign finance regulations, it might be said, will probably produce perverse consequences. Political money will inevitably find ways to circumvent whatever rules are

68. See text accompanying note 22 supra.

69. Buckley, 424 U.S. at $23,29,45$.

70. Id. at 43,47 .

71. Id. at 45 .

72. Id. at 47.

73. See Burt Neuborne, Campaign Finance Reform: The Constitutional Question: Buckley's Analytical Flaws, 6 J.L. \& PoL'y 111, 117 (1997) (arguing that contribution and expenditure caps should both be subject to reasonable regulation). 
imposed..$^{74}$

These criticisms of Buckley are important, but they should not be presented, as they usually are, as if they addressed the constitutional questions at stake..$^{75}$ They could address those questions only on the supposition that the constitutional analysis called for in Buckley boils down to a cost-benefit balancing of how much campaign speech has to be suppressed in order to yield the desired anticorruption results. It is hard to fault anyone who reads Buckley as calling for this kind of cost-benefit analysis, given the ample dose of balancing rhetoric in the opinion. Nevertheless, it is a mistake to do so.

With respect to the anticorruption effects of the independent expenditure limitations, the Buckley Court was not engaging in superlegislative, costbenefit review of the policy merits of Congress's statute. Rather the Court was holding that the purpose of the $\$ 1,000$ per year per person cap could not be fully, satisfactorily explained in terms of combating corruption. The Court was saying, in short, that the Congres's statute had to be understood by reference to some other governmental purpose. And this conclusion was correct.

What other purpose? There was no secret about it. The government's lawyers in Buckley expressly acknowledged the other purpose and indeed defended the statute on this ground. The expenditure limitations were "aimed in part at equalizing the relative ability of all voters to affect electoral outcomes." 76 This was and is the real issue posed by Buckley: whether Congress can limit spending on political advocacy in order to offset the phenomenally greater ability of wealthy people and groups to broadcast their messages to the electorate.

The Buckley Court unequivocally answered this question in the negative:

[T]he concept that government may restrict the speech of some ... in order to enhance the relative voice of others is wholly foreign to the First Amendment, which was designed "to secure 'the widest possible dissemination of information from diverse and antagonistic sources."... The First Amendment's protection ... cannot properly be made to depend on a person's financial ability to engage in public discussion. ${ }^{77}$

A deep question of First Amendment theory is in play here. Stated briefly,

74. See, e.g., Samuel Issacharoff \& Pamela S. Karlan, The Hydraulics of Campaign Finance Reform, 77 TEX. L. REV. 1705 (1999) (postulating the "Third Law of Political Motion," i.e., reform efforts will cause a series of reactions that result in political money simply being re-routed).

75. See, e.g., Lillian R. BeVier, Money and Politics: A Perspective on the First Amendment and Campaign Finance Reform, 73 CAL. L. REv. 1045, 1062-66 (1985) (arguing that contribution and expenditure caps should both be subject to strict scrutiny). But see Issacharoff \& Karlan, supra note 74, at 1706-07 (taking care not to conflate the policy issues with the constitutional issues).

76. Buckley, 424 U.S. at 17.

77. Id. at 48-49 (citations omitted). 
the question is the place of equality in the law of free speech. It is by no means obvious that the freedom of speech entails a freedom to buy as much political speech as one can afford; the right to vote, after all, does not entail a right to buy as many votes as one can afford. I myself share the fairly conventional view that democracy is harmed where wealth can dominate election results. ${ }^{78} \mathrm{It}$ is certainly no answer to say, with the Buckley majority, that First Amendment rights "cannot properly be made to depend on a person's financial ability."79 This proposition hardly cuts in favor of the Buckley outcome. On the contrary, one might very plausibly defend expenditure ceilings on the ground that the right to a say in the political process "cannot properly be made to depend on a person's financial ability."80

Nevertheless, the analysis I have suggested so far supports Buckley's result. As measures aimed at equalizing influence, Congress's expenditure limitations were designed to prohibit some people from engaging in protected speech on the ground that such speech would succeed only too well-as speech. The obvious concern was that excessive campaign advertising by the wealthy will persuade people who hear or see it. The Buckley Court made this point: "it is beyond dispute," the Court stated, that Congress's interest in preventing the wealthy from engaging in too much political communication "arises in some measure because the communication ... is itself thought to be harmful."

By contrast, attempting to combat corruption in campaign financing does not presuppose any harm resulting from the persuasiveness of campaign advertising. The danger of corruption is triggered as soon as there is the giving and receiving of money. It makes no difference whether individuals put cash directly into a candidate's bank account, pay for a candidate's private airplane,

78. For pro-equality critiques of Buckley, see, e.g., John Rawls, The Basic Liberties and Their Priority, in LIBERTY, EQUALITY, AND LAw: SElECTED TANNER LECTURES ON Moral PhILOSOPHY 1, 75-79 (Sterling M. McMurrin ed., 1987); Cass R. Sunstein, Political Equality and Unintended Consequences, 94 Colum. L. REv. 1390 (1994). For criticism of this criticism, from both a First Amendment and political theory perspective, see, for example, Kathleen M. Sullivan, Against Campaign Finance Reform, 1998 UTAH L. Rev. 311; Kathleen M. Sullivan, Political Money and Freedom of Speech, 30 U.C. DAvis L. REv. 663 (1997).

79. Buckley, 424 U.S. at 49.

80. Moreover, the Buckley Court was almost certainly wrong in saying that the very "concept" of "restricting the speech of some... to enhance the relative voice of others" is "foreign" to the First Amendment. 424 U.S. at 48-49. For example, the well-known Red Lion case, upholding the "fairness doctrine" that used to force broadcasters to give a rightof-reply to candidates who were criticized on air, appears to have been a case of "restricting the speech of some ... to enhance the relative voice of others." See Red Lion Broad. Co. v. FCC, 395 U.S. 367 (1969); see also Turner Broad. Sys., Inc. v. FCC, 520 U.S. 180 (1997) (upholding requirement that cable operators carry a designated percentage of local broadcast programming).

81. Buckley, 424 U.S. at 17 (quoting United States v. O'Brien 391 U.S. 367, 382 (1968)) (internal quotation marks omitted; emphasis added). 
or pay for a candidate's campaign advertisements. If the purpose of the expenditure caps had been solely to combat corruption, they would have been constitutional. In fact, however, as the Buckley Court's narrow-tailoring analysis helped to show, the expenditure caps were framed to equalize influence, not merely to combat corruption. Accordingly, the expenditure caps were properly ruled unconstitutional. The First Amendment does not allow government deliberately to stop protected speech on the ground that it will be harmfully persuasive. Period.

But this conclusion did not apply to the contribution limitations, which is why the Court correctly upheld them. With respect to contributions, there was no evidence that Congress had acted because of any harms alleged to result from expression. To be sure, campaign contributions are (or can be) politically expressive. Indeed, a contribution can signal not only that an individual supports a candidate, but, in its amount, how much he supports a candidate. It follows that limiting contributions certainly can have a significant effect on individuals' ability to express their views-more of an effect than the Buckley Court conceded.

But a law limiting contributions in order to avoid corruption does not punish anyone for such expression. The danger of corruption does not flow from a contribution's communicative status-its status as a speech act expressing the contributor's political opinions. The harm lies in the money as potential quid pro quo, not in the money as speech. Bribery may be highly expressive of the payor's political opinions, but it remains criminalizable because it can be prohibited without reference to any protected opinion it might express. Thus the contribution caps were properly upheld.

This analysis has important implications for current campaign finance reform efforts. A generally applicable conduct law, as I have said, does not become unconstitutional or even subject to First Amendment heightened scrutiny just because it impinges on persons who are speaking through that conduct. Spending money is conduct, and as a result, although spending money may (like all other conduct) be expressive, a generally applicable spending regulation can in some cases be constitutionally unproblematic.

The First Amendment decisive question in regulating spending is whether the regulation singles out speech for special restrictions. Thus a law banning government employees from receiving compensation for speechmaking, but not for other profitable moonlighting activities, is properly held unconstitutional. ${ }^{82}$ So is a law imposing special restrictions on the payment of persons hired to engage in charitable solicitation. ${ }^{83}$ But a law regulating how

82. See, e.g., United States v. Nat'l Treasury Employees Union, 513 U.S. 454 (1995) (holding unconstitutional a law that prohibits federal employees from accepting compensation for making speeches or writing articles even in an unofficial capacity).

83. See, e.g., Vill. of Schaumburg v. Citizens for a Better Env't, 444 U.S. 620 (1980) 
much money may or must be spent on a particular activity raises no free speech problem so long as the law does not pick out spending-to-speak as the activity subject to the regulation, and so long as the harms against which the law is directed are independent of any communication that might result from such spending.

The key, then, to a constitutional campaign expenditure cap is that the law must be tailored in such a way as to dispel the claim that it is directed at speech deemed harmfully persuasive. One possibility has been suggested by Ian Ayres and others: Congress might subject all campaign-related spending (including both contributions and expenditures) over a designated amount to an anonymity requirement. The object of an anonymity requirement has nothing to do with the potential persuasiveness of the speech on which the money might be spent. It permits the wealthy to spend as much as they like on behalf of whatever candidate they like. Instead the harms that it addresses are noncommunicative: Its purpose is to make it harder for persons to buy political influence.

Another possibility would be to broaden campaign spending limits to ensure that they are totally generally applicable to all campaign spending, not just campaign spending on speech. In this alternative, no special restrictions would attach to spending-on-speech that do not attach to all other forms of campaign spending, such as spending on accommodation, transportation, private investigators, and so on. To be sure, the objection here will be that all or nearly all campaign spending might be said to be spending-to-speak, and that the singling out of campaign-related spending is therefore on its face a targeting of "First Amendment activity." These objections are strong, and it might be impossible, practically speaking, to draft a campaign spending law that did not effectively target spending-to-speak. But at the very least the category of "First Amendment activity" needs to be disaggregated. Voting, together with the entire electoral process, is today considered a kind of massive "First Amendment activity," but of course we have myriad regulations of voting and the electoral process as a whole; indeed such regulation is explicitly constitutionally mandated. The fact that laws single out the electoral process for special regulations does not in itself violate any constitutional norm.

Accordingly, in principle, a generalized spending cap directed at limiting the total amount of money spendable in political campaigns should be constitutional, provided it is genuinely tailored-not narrowly tailored, but broadly tailored-to address the noncommunicative harms of having too much money in the political process. These noncommunicative harms are not limited to conventional quid-pro-quo corruption; they also include excessive responsiveness of politicians to the interests of the wealthy and excessive time

(holding unconstitutional a village ordinance prohibiting door-to-door or on-street solicitation of contributions by charitable organizations not using at least $75 \%$ of their receipts for "charitable purposes"). 
spent by politicians raising funds. It is wholly reasonable that a legislature might want to redress these noncommunicative harms by imposing an overall cap on campaign spending.

To be sure, Congress had enacted an overall spending cap in the 1970s arguably similar to the one just described, and the Buckley Court struck it down. But the Buckley Court read the statute as applying specifically to expenditures on speech, and in any event, as discussed above, the Buckley circumstances made clear that Congress had deliberately acted there to limit some speech (that of the wealthy) because of its excessive persuasiveness. ${ }^{84}$ Buckley, therefore, should not be understood to hold that a fully generalized campaign spending cap, genuinely tailored to address the noncommunicative harms threatened by the spiraling costs of campaigning, would be unconstitutional.

\section{Homosexuality and the Scouts}

Perhaps it will be appealing-perhaps not-that purposivism offers a simple answer to a case as controversial as the Supreme Court's recent decision involving homosexuality and the Boy Scouts. ${ }^{85}$ Simplifying slightly, I will consider the case on the following facts.

New Jersey has a public accommodations statute forbidding discrimination on the basis of sexual orientation. A New Jersey chapter of the Boy Scouts of America revoked the membership of an assistant "scoutmaster" because of his homosexuality. The individual sued in state court and won. On appeal to the United States Supreme Court, the Scouts claimed that New Jersey's law violated their First Amendment rights of "expressive association." The Scouts argued that New Jersey's statute unconstitutionally interfered with their ability to express and to teach their views-in particular, the view that homosexuality is "not morally straight."

The Supreme Court agreed. The Court found that "the forced inclusion of [the plaintiff] would significantly affect [the Scouts'] expression." 87 Indeed, New Jersey's law would "force the organization to send a message" that the Scouts emphatically did not want to send-"that the Boy Scouts accepts homosexual conduct as a legitimate form of behavior."'s8 Accordingly, it was necessary to place the Scouts' "associational interest in freedom of

84. See text accompanying notes 80-81 supra.

85. Boy Scouts of Am. v. Dale, 120 S. Ct. 2446 (2000).

86. Id. at 2453; see also Dale v. Boy Scouts of Am., 734 A.2d 1196 (N.J. 1999), rev'd, 120 S. Ct. $2446(2000)$.

87. See Boy Scouts, 120 S. Ct. at 2455.

88. Id. at 2454. 
expression ... on one side of the scale, and the State's interest on the other." 89

To strike the right balance, the Court applied a version of strict scrutiny: The Boy Scouts' First Amendment interests could be overridden only if New Jersey's law "serve[d] compelling state interests ... that cannot be achieved through means significantly less restrictive of associational freedoms." 90 Applying this test in the cost-benefit, justificatory mode described above, the Court concluded that the "state interests embodied in New Jersey's public accommodations law do not justify such a severe intrusion on the Boy Scouts' rights to freedom of expressive association." "91

As usual, the idea that this conclusion was reached through any serious, intelligent effort to measure and "balance" the pertinent interests is belied by the actual opinion. There is virtually not a word in Boy Scouts about what New Jersey's interests were, nor about the calculation or reasoning that yielded the conclusion that these interests did not "outweigh" the associational "burdens" suffered by the Scouts, nor about the extent to which attainment of the state's interests, whatever they were, would or would not be hampered by the need to make exceptions for associations like the Boy Scouts.

But the sketchiness of the Court's cost-benefit analysis is not the real problem. A much more thorough analysis of the social value of heterosexuality (or homosexuality) would have been equally problematic. What the Court should have said was this: The Scouts' argument failed to state a First Amendment claim.

The Boy Scouts wanted an exemption from an otherwise constitutional law regulating conduct on the ground that such a law, as applied to them, posed significant burdens on their First Amendment freedoms. But to repeat: A conduct law of general applicability, not enacted to target speech, does not become a First Amendment problem when it confronts persons who want to engage in the prohibited conduct for expressive reasons.

The entire debate in terms of which Boy Scouts largely played out was constitutionally beside the point. The judges who found in favor of Dale, both state and federal, concluded as a factual matter that excluding homosexuals was not central to and indeed was inconsistent with the Boy Scouts' fundamental values: New Jersey's law neither "impose[d] any serious burden" on the Scouts' ability to pursue their "shared goals," nor "force[d]" the Scouts "to communicate any message" opposed to the organization's fundamental creed.92 These assertions may or may not be correct. The truth, however, is that antidiscrimination laws do centrally interfere with the ability of many people to communicate certain messages and values. No good is done, analytically or

89. Id. at 2456.

90. Id. at 2451 (quoting Roberts v. United States Jaycees, 468 U.S. 609, 623 (1984)).

91. Id. at 2457 .

92. 120 U.S. at 2460 (Stevens, J., dissenting); see also Dale, 734 A.2d at 1223. 
normatively, by denying this fact.

But this fact is constitutionally irrelevant. Stipulate that New Jersey's antidiscrimination law would have prevented the Boy Scouts from expressing a message they want to express. Stipulate even that the law would have forced the Scouts to communicate a message they did not want to communicatesupport for homosexuality. The Scouts would still be situated no differently than a tax protester, who is also prevented from communicating a message he wants to communicate and who is also forced, as much as the Scouts are, to send a message he does not want to send-support for the United States government. The tax protester's most effective means (perhaps his only effective means) of communicating his lack of support for the United States might be his refusal to pay his taxes. But he does not for this reason obtain an immunity from the tax code.

Every law prohibits some persons from expressing opinions or values in the way they want to express them. This was A's claim when he was arrested for speeding. Every law has the arguable effect of forcing some people to communicate a message (if only support for the law) that they do not wish to convey. This fact is never understood to render laws unconstitutional as applied to such persons. Why should it suddenly do so when the law that people want to break is a law banning discrimination against homosexuals?

If First Amendment rights were really to be analyzed in the balancing-test terms invoked by the Boy Scouts Court, then every time a person wanted to break a law for expressive reasons, there should be equally painstaking judicial review of the pertinent costs and benefits-and especially of the state's ability to satisfy its interests, without paying too high a price, while making exceptions for "expressive law-breakers." This is not the way free speech analysis has ever worked - or should work. Purposivism explains why. Provided that the law's purpose is to target doing rather than speaking, and provided that the law is not selectively enforced to target speech, individuals do not obtain a First Amendment "pass" from generally applicable conduct laws just because they want to break the law for expressive reasons.

The Supreme Court once held, in a case called Sherbert $v$. Verner, that when laws of general applicability substantially burden an individual's religious practices, the law could not be applied to this individual in the absence of compelling justification..$^{93}$ Subsequently the Court overturned this doctrine, finding it unworkable in practice and unsound as a matter of law. ${ }^{94}$ First Amendment purposivism essentially holds that a Sherbert-style regime is unacceptable, not only for free exercise but also for free speech. Individuals who want to engage in "First Amendment activity" through prohibited conduct

93. 374 U.S. 398 (1963).

94. Employment Div., Dep't of Human Res. of Oregon v. Smith, 494 U.S. 872 (1990). 
do not get an exemption; nor do they get special scrutiny of the law before it can be applied to them. Obviously, the free exercise piece of this larger picture is another story; 95 the essential point here is that, from a purposivist perspective, there can be no "disparate impact" free speech claims. There is no free speech "conscientious objector." Laws violate the freedom of speech only when state actors seek to punish persons for speaking, not when laws merely have the effect of preventing persons from speaking the way they want to. ${ }^{96}$

It will be said that I have given short shrift to the "freedom of association." Surely, someone will object, it cannot be true that the right to associate is never implicated by a law of general applicability. Suppose a state applied its discrimination laws to an individual's choice of friends, or sexual intimates, or spouse. Wouldn't everyone agree that discrimination laws could not be constitutionally applied to such private, intimate associations?

Yes, but the right of "intimate association" was not at issue in Boy Scouts and has nothing to do with the free speech rights discussed here. Remember that there are two different constitutional rights of association. The right of "intimate association," sometimes classified as a branch of the right of privacy, is distinct from the right of "expressive association" protected by the First Amendment. ${ }^{97}$ Although the right of intimate association may well apply to private clubs of very small size, it is well established that an organization as large and as generally open to the public as the Boy Scouts is not an "intimate association" for constitutional purposes. ${ }^{98}$ Rather, the associational right at issue in Boy Scouts - the First Amendment associational right-was solely the

95. For more on First Amendment purposivism in the religious freedom context, see Jed Rubenfeld, Antidisestablishmentarianism: Why RFRA Really Was Unconstitutional, 95 MicH. L. REv. 2347 (1997).

96. Boy Scouts is not only similar to the now-repudiated Sherbert $v$. Verner. Taken to its logical conclusion, Boy Scouts may be that case all over again. Religious activity is clearly expressive activity, and religious groups are expressive associations par excellence. Many free exercise claims can, as a result, be recast as a freedom of speech or freedom of expressive association claims. Accordingly, many claims that used to be brought under Sherbert-almost all of which were rejected, which is what finally led the Court to recognize that it could not honestly apply, and was not honestly applying, strict scrutiny in such cases-could now be brought again under Boy Scouts. Consider, for example, a Christian homeowners' association that wants to exclude blacks, women, Jews, unmarried couples, or anyone else on religious grounds. Smith tells us that these homeowners cannot demand strict scrutiny under Sherbert. No matter-now they can do so under Boy Scouts.

97. E.g., Roberts v. United States Jaycees, 468 U.S. 609, 617-18 (1984).

98. See id. at 618-21. The Boy Scouts Court quoted and did not disturb the New Jersey supreme court's finding 'that the Boy Scouts' 'large size, nonselectivity, inclusive rather than exclusive purpose, and practice of inviting or allowing nonmembers to attend meetings, establish that the organization is not "sufficiently personal or private to warrant constitutional protection" under the freedom of intimate association." Boy Scouts, $120 \mathrm{~S}$. Ct. at 2450 (quoting Dale, 734 A.2d at 1221 (quoting Bd. of Dir. of Rotary Int'l v. Rotary Club of Duarte, 481 U.S. 537, $546(1987))$ ). 
right "to associate for expressive purposes." 99

The difference is critical. The right of intimate association blocks government from dictating to people the kind of persons with whom they will have close, personal relationships. This right can be violated when laws of general applicability are applied to intimate contexts, a result consistent with purposivism. If a state were to apply its discrimination laws to intimate relationships, the state would be purposefully doing what the right of intimate association says the state cannot do: dictating to individuals what sort of persons they can choose as friends, lovers, and so on. By contrast, the purpose disallowed by the First Amendment is the purpose to punish people for speaking, and applying a standard discrimination law to someone who wants to discriminate for expressive reasons does not punish this person for what he is saying through his conduct. It punishes him solely for what he is doing. Applying antidiscrimination laws to a person's dating choices would presumably be unconstitutional because it would violate the right of intimate association; but it would not abridge the freedom of speech.

The First Amendment's associational right protects individuals' freedom to join together with others to engage in "First Amendment activities." It is "a right to associate for the purpose of engaging in those activities protected by the First Amendment-speech, assembly, petition for the redress of grievances, and the exercise of religion." 100 This right is of crucial First Amendment importance. It protects organizations like the NAACP from being banned or persecuted because state actors do not like their First Amendment activitypublishing, advocating, bringing lawsuits, and so on. It protects an individual from being punished or harassed for being a member of an organization like the NAACP. In other words, the "freedom of expressive association" is implicated precisely when the state targets an association or its members because of the expression in which they seek to engage. It is not violated by a conduct law of general applicability that happens adversely to affect individuals' ability to express their views through their associational choices.

Take seriously for a moment the regime ostensibly embraced by the Court in Boy Scouts. The Court's requirements for triggering strict scrutiny are not stringent. They can be easily stated. It was sufficient that the Boy Scouts "engage in expressive activity" and that forcing the Scouts to comply with New Jersey law "would significantly affect [their] expression." 101 On the first point,

99. Boy Scouts, 120 S. Ct. at 2446.

100. Roberts, 468 U.S. at 618.

101. "Given that the Boy Scouts engages in expressive activity, we must determine whether the forced inclusion of Dale as an assistant scoutmaster would significantly affect the Boy Scouts' ability to advocate pubic or private viewpoints." Boy Scouts, $120 \mathrm{~S}$. Ct. at 2452. "Having determined that the Boy Scouts is an expressive association and that the forced inclusion of Dale would significantly affect its expression, we inquire whether the application of New Jersey's public accommodations law to require that the Boy Scouts 
the Court expressly held that "associations do not have to associate for the 'purpose' of disseminating a certain message in order" to claim First Amendment protection. ${ }^{102}$ An "assocation must merely engage in expressive activity that could be impaired in order to be entitled to protection."103 On the second, the Court was equally clear that the association's own attestations of its beliefs must be accepted by the judiciary, together with the association's own understanding of "what would impair its expression." 104

If this analysis is taken seriously, most associations should now be able to go to court and demand strict First Amendment scrutiny of most discrimination laws as applied to them. An obvious implication is that a lobbying firm or law firm (associations almost entirely devoted to First Amendment activity) should be able to discriminate against blacks or women if the firm seeks to advocate the view that treating the races or sexes equally is not "a legitimate form of conduct." But more than this: Almost all associations-every business, every apartment complex, every residential neighborhood-should be able to take advantage of the Boy Scouts regime.

Almost all associations "engage in expressive activity." Businesses certainly do: in their commercial advertising, in their choice of what to sell, and in their hiring practices. Neighborhood associations and apartment complexes also do; deciding whom to have in or out of your community expresses a great deal. As a result, ordinary discrimination laws can unquestionably "significantly affect" the expression of such groups. Hence virtually any association-commercial, residential, and so on-that wants to discriminate should now be able to file an action under the First Amendment and to demand strict scrutiny of virtually every discrimination law applied against it.

And if strict scrutiny were honestly applied in such cases, many of these groups should win. After all, why shouldn't states be obliged to accommodate discrimination-exemptions for, say, small businesses or small neighborhoods genuinely dedicated to expressing the belief that blacks, Jews or women don't belong in the same places as whites, Christians, or men? Under cost-benefit strict scrutiny, First Amendment rights should and will typically prevail over a governmental interest in legislating morality, which is what discrimination laws undoubtedly do.

But the difficulties do not stop even here. There is no reason why the Boy Scouts regime should apply only to discrimination laws.

accept Dale as an assistant scoutmaster" violates the First Amendment. Id. at 2455 . The opinion goes on from the latter point to apply the compelling state interest test. See id. at 2456-57.

102. Id. at 2454.

103. Id.

104. Id. at 2453. 
Imagine an organization claiming to believe that the federal government is not "morally straight." This organization advocates the abolition of the federal income tax and claims that being forced to pay this tax "significantly affects its expression." This organization happens also to be for-profit-and very profitable (perhaps its name is Microsoft). Remember that under Dale, the association does not need to have been formed to advocate a particular message in order to claim strict scrutiny of laws that significantly affect its expression. It "must merely engage in expressive activity that could be impaired in order to be entitled to protection." 105 Why, then, should this organization have to pay its taxes and be "force[d]" thereby to "send a message" it does not endorse?

Someone will respond that Boy Scouts provides an answer to this hypothetical. The Boy Scouts Court expressly distinguished New Jersey's discrimination law, which "directly and immediately affects associational rights," from laws that have "only an incidental effect" on speech or association, which are properly subjected to the less exacting O'Brien balancing test. ${ }^{106}$ Accordingly, it might be said, an association challenging a tax law could demand only O'Brien review, because such a law does not "directly and immediately affect associational rights."

But tax laws $d o$ "directly and immediately affect associational rights." The Supreme Court has recognized (in Buckley, among other cases) that payments by individuals to political organizations are themselves acts of First Amendment association. ${ }^{107}$ This holding is undoubtedly correct: A law forcing people to contribute to the Pat Buchanan campaign would obviously be seen as a "direct and immediate" impingement on the freedom of expressive association. Indeed such a law would correctly be seen as forcing some individuals to convey a message they do not endorse. Thus under Boy Scouts, an association sincerely committed to antifederal, antitax views should have just as plausible a First Amendment claim against the federal income tax (as applied to them) as the Scouts had against New Jersey's discrimination laws.

It will be said, however, that I am still slighting the decisive role in civil society played by private organizations, which are necessary to intermediate between individual and state, and whose associational decisions must be insulated from governmental control if they are to be able to serve their crucial political and social functions. But this argument proves too much. The private organizations that clearly play the most important intermediating and lifeshaping role in current American civil society are profit-making organizations, as to which no one seems to doubt the applicability of antidiscrimination statutes.

Someone might still object that certain non-commercial associations

105. Id. at 2454 .

106. Id. at 2457.

107. See, e.g., Buckley v. Valeo, 424 U.S. 1, 18 (1976). 
cannot be forced to obey antidiscrimination laws without losing their fundamental character. The standard reference here is the Ku Klux Klan. Could a state force the Klan to accept blacks?

The answer is yes. Most associations are defined by their associational commitments, but they do not therefore enjoy constitutional immunity when their commitments run afoul by the law. The American Association of Rapists, were there such a thing, would presumably be commited to rape; in a sense, it could not really be the American Association of Rapists if its members did not commit rape. Is that fact supposed to generate First Amendment concern? The Klan is not the only organization that opposes laws "directly and immediately affect[ing] associational rights." Pro-polygamy associations oppose bigamy laws; pro-pederasty associations oppose statutory rape laws (among other things). Does anyone think that these associations have a First Amendment right to practice what they preach?

Discrimination laws do not become unconstitutional when they happen to run up against persons who, whether individually or in association with others, claim that they want or need to discriminate for expressive reasons. A state can apply its racial discrimination statutes to the Klan just as the federal government can apply its racial discrimination laws to a newspaper's hiring decisions, even if that newspaper happens to be committed to promoting racist views. A very different case would be presented if a state sought to block the Klan from excluding persons, white or black, who do not sign on to its ideology, and one imagines that the Klan would find very few blacks who do sign on. But so long as the state did not single out the Klan because of its views, and so long as the state permitted the Klan to exclude people who did not share those views, Klan members would have no claim that the state was punishing them for, or preventing them from, exercising their rights of expressive association.

I am not arguing that antidiscrimination laws can be applied unproblematically to every association. Special considerations would apply in some cases: for example, to a church's choice of minister. While there is no general First Amendment pass for persons who seek to violate a law for religious purposes, a narrower immunity may well be applicable to a church's choice of minister, either on "intimate association" grounds or on Establishment Clause grounds. ${ }^{108}$ Nor am I arguing that states can force one political party to allow members of other parties to vote in their primaries.

108. The First Amendment's bar against laws "respecting an establishment of religion" does more than bar "establishing a religion" in the familiar sense of that phrase. See, e.g., Rubenfeld, Antidisestablishmentarianism, supra note 95, at 2350. A church is an "establishment of religion" in an obvious sense (but not the sense that we ordinarily attribute to those words), and read in this sense, the Establishment Clause might well prohibit governmental regulation of internal church governance. 
Individuals and associations have no First Amendment right to discriminate on grounds of race, sex, and so on; but they may have a First Amendment right to "discriminate" against people who refuse to support their ideological agendas. Nor, finally, am I addressing claims based on the "assembly" clause of the First Amendment, which might be said (at such a stretch, however, that one would be obliged to wonder why the reference to the text was even thought relevant) to protect the Boy Scouts' choice of who may and may not "assemble" at their meetings. The argument $I$ have made concerns the freedom of speech, and the point is that this freedom offers no immunity to an organization like the Boy Scouts when it seeks an exemption from laws whose purpose is not to punish anyone for speaking.

Perhaps someone will claim, however, that antidiscrimination laws do punish people for speaking. As noted, racial and other forms of discrimination can undoubtedly and powerfully communicate opinions. Doesn't this mean that discrimination laws do in fact punish people for expressing their opinion?

No. Once again, to punish people as a result of speaking is not the same as punishing them for speaking. Antidiscrimination statutes are in this respect no different from any other statutes legislating morality. Polygamy laws also ban an activity that in most cases is highly expressive. (Indeed if the reasoning of Boy Scouts were taken seriously, polygamy laws should now demand strict scrutiny because they impinge significantly on a form of expressive association.) But no one has ever supposed that polygamy laws violate the freedom of speech, and the reason is that the immorality they condemn is the (supposed) immorality of what is being done-being married to more than one person-not what is being said.

The First Amendment does not enact libertarianism. It is untroubled by morality laws so long as the state does not deem it immoral and therefore illegal to say something. The difference will strike readers as razor-fine, and perhaps it is, but from the First Amendment's viewpoint, prohibiting conduct on moral grounds is identical to prohibiting conduct on health or safety grounds.

There is a view of antidiscrimination laws according to which the harm that such laws target is precisely a communicative harm. On this view, the reason for prohibiting discrimination is that discrimination communicates messages not only hurtful to many persons but invidious and harmful to society as a whole. People who make this argument seem not to be conscious that they are in fact asserting that antidiscrimination laws are unconstitutional. (Compare: "The reason why flag burning is prohibited is that flag burning communicates a message about the United States not only hurtful to many but invidious and harmful to society as a whole." This proposition is not a defense of flag burning laws; it is an acknowledgment of their unconstitutionality.) Discrimination is undoubtedly expressive, but to ban it because of its expressiveness is to violate the First Amendment. Discrimination is 
prohibitable on the ground that blacks, women, and so on, are entitled as a matter of justice to the same treatment as whites, men, and so on. It is not prohibitable on the ground that discrimination expresses offensive and harmful attitudes or messages.

Does a law like Title VII ban discrimination because of its expressiveness? Imagine an employer who refuses to hire a black (on racial grounds), but does not communicate a racist message through this action. How might this happen? It might happen, for example, if the employer misrepresents the true basis for his refusal to hire. Can such an employer plead as a defense against a Title VII claim that he assiduously covered up his racist motives and thereby managed not to communicate any offensive message? Obviously not. Title VII reaches acts of discrimination whether or not the discriminator was communicating through them. Of course discrimination can be expressive, but standard antidiscrimination laws like Title VII ban discriminatory actions regardless of their expressiveness.

The American legal system condemns racial and sexual discrimination on moral grounds. But condemning conduct as immoral is not the same as condemning it for expressing something immoral. So long as antidiscrimination laws are not narrowly tailored in a suspicious way-so long as they apply generally and embrace discriminatory conduct regardless of whether the discriminator was communicating through that conduct-there is no reason why judges should deem discrimination laws to have an impermissible, speech-suppressing purpose.

But this entire argument, to return to Boy Scouts, is off the mark. If the purpose behind an antidiscrimination law is to suppress the expression of an idea deemed immoral or offensive, the law is unconstitutional altogether. But if we assume what is conceded in Boy Scouts-that New Jersey's antidiscrimination law is perfectly constitutional as generally applied-the Boy Scouts have no special claim against its application to them. They have no special First Amendment claim just because they are discriminating-to-speak.

Justice William Brennan, ironically enough, laid the foundation for Boy Scouts in the Roberts case, which upheld a Minnesota sex discrimination statute as applied to the United States Jaycees, a national young men's "civic association" that denied full voting membership to women. ${ }^{109}$ Employing prototypical balancing-test rhetoric, Justice Brennan stated that the law was constitutional even though it "burden[ed]" the "freedom of association." "The right to associate for expressive purposes," wrote Brennan, "is not...

109. Roberts v. United States Jaycees, 468 U.S. 609 (1984); see also New York State Club Ass'n v. City of New York, 487 U.S. 1 (1988) (upholding against facial First Amendment challenge a law prohibiting racial, religious, or sex discrimination in any institution, club, or place of accommodation having more than 400 members). 
absolute."110 As applied to the Jaycees, the First Amendment "burden" was not "serious," and the state's "compelling interest in eradicating discrimination against its female citizens justifie[d]" that burden."11

Roberts is rightly decided, but wrongly reasoned. Or rather, the case was rightly reasoned, but to find the right reasoning, one has to look for the passage where all the balancing rhetoric drops away:

[T] he Minnesota Act does not aim at the suppression of speech, does not distinguish between prohibited and permitted activity on the basis of viewpoint, and does not license enforcement authorities to administer the statute on the basis of such constitutionally impermissible criteria. Nor [was the Act] applied in this case for the purpose of hampering the organization's ability to express its views. ${ }^{112}$

Here the Roberts Court stated the case from the purposivist perspective. And here the analysis should have come to an end. ${ }^{113}$

If it had, First Amendment doctrine would have seen the Boy Scouts case for what it was: a claim that people are constitutionally entitled to violate a conduct law of general applicability because they have important expressive reasons for doing so. There is no such First Amendment immunity. There is no more a right of discrimination-to-speak than there is a right of speeding-tospeak or tax-evasion-to-speak. Boy Scouts is the Sherbert v. Verner of free speech law. It will prove subject to all the embarrassments that Sherbert was. ${ }^{114}$ And it will have, one may hope, the same longevity.

\section{ANTI-ORTHODOXY}

Earlier I deferred the larger issues of First Amendment theory raised by First Amendment purposivism, in particular the question of what ultimate

110. Roberts, 468 U.S. at 623.

111. Id.

112. Id. at 623-24 (citation omitted).

113. Hurley - the parade case-is not to the contrary. In Hurley, the Supreme Court overturned a state court order requiring the organizers of a privately organized St. Patrick's Day parade to permit plaintiffs to march in their parade under a banner identifying themselves as homosexual and/or bisexual Irish-Americans. Hurley v. Irish-American Gay, Lesbian and Bisexual Group of Boston, 515 U.S. 557 (1995). But the organizers of the Hurley parade were not resisting the state's generally applicable conduct law; they were not trying to exclude homosexuals from the parade. Rather, they were resisting an order compelling them to include in the parade an actual speech act they did not want to include. Id. at 572 (parade organizers "disclaim[ed] any intent to exclude homosexuals as such, and no individual member of [plaintiffs' group] claim[ed] to have been excluded from parading as a member of any group that the [organizers had] approved to march. Instead, the disagreement goes to the admission of [the Gay, Lesbian and Bisexual Group] as its own parade unit carrying its own banner.") (emphasis added).

114. See text accompanying note 93-96 supra. 
normative principle purposivism is supposed to serve. This Part seeks to answer that question. In the process it deals with another problem postponed above: the problem of saying how the categories of unprotected speech (libel, incitement, and so on) would be treated in a purposivist free speech jurisprudence.

\section{A. The Anti-Orthodoxy Principle}

The freedom of speech as I have described it is intended to honor a simple principle. The principle takes shape from the basic intuition that individuals have the "right to their opinion," that they cannot be punished for having or for expressing a particular opinion, regardless of the topic, regardless of how foolish or trivial their opinion may be, and regardless even of how unpleasant or dangerous state actors might think it. This is the idea, which seems to be part of the bedrock of American free speech law, behind the First Amendment's categorical resistance to balancing.

It is clear, however, that this instinct stands in need of conceptualization. And clarification: A doctor can, after all, be punished for expressing his opinion-if he was negligent in doing so. In a sense, the entire object of this Article is to see how far the logic of this basic First Amendment intuition extends.

A principle deeply familiar to First Amendment jurisprudence, although perhaps not formalized, elaborates on this intuition. I will call it the antiorthodoxy principle, in deference to Justice Robert Jackson's famous formulation:

If there is any fixed star in our constitutional constellation, it is that no official, high or petty, can prescribe what shall be orthodox in politics, nationalism, religion, or other matters of opinion or force citizens to confess by word or act their faith therein. If there are any circumstances which permit an exception, they do not now occur to us. ${ }^{115}$

Notice the absolutism of Justice Jackson's formulation, an absolutism absolutely incompatible with cost-benefit, balancing approaches to the First Amendment. But what does it mean to proscribe the prescribing of orthodoxies, and what is the domain in which this absolute principle applies absolutely?

Two points are crucial. First, orthodoxy here refers to a regime of professed belief. A state does not "prescribe what shall be orthodox" when it merely dictates what must and must not be done, but only when it dictates what beliefs must and must not be expressed. Thus while morality is undoubtedly one of the "matters of opinion" to which the anti-orthodoxy principle applies,

115. W. Va. Bd. of Educ. v. Barnette, 319 U.S. 624,642 (1943). 
the First Amendment does not bar legislators from enacting their moral judgments into law-provided they do not punish people for criticizing these judgments or expressing different attitudes. To "prescribe what shall be orthodox" on a "matter of opinion" does not mean making law on the basis of opinion. It means prescribing what opinions must or must not be expressed.

Second, the domain in which the anti-orthodoxy principle applies is not unlimited. There are, for example, places where it does not apply. In court, for example, people do not always have the right to express their opinions. Probably the best way to express this limitation is to say, following Robert Post's important distinction, that different First Amendment rules apply when government is exercising its "managerial" (as opposed to "regulatory") functions.

A more important limitation: The domain of speech to which the antiorthodoxy principle applies is not all-encompassing. There is a kind of orthodoxy that government can and does enforce every day, even in the sense of prescribing what people must and must not say. I refer to the orthodoxy of true and false facts. While it is true that "there is no such thing as a false idea" under the First Amendment, ${ }^{116}$ there is clearly such a thing as a false fact. The laws of libel, fraud, perjury, and so on, all punish people for speaking falsely on matters of fact.

Why is it tolerable for state actors to declare the truth about how many miles a certain car has been driven, but not how many gods there are? The answer is in part that an injunction against false statements of fact is an orthodoxy that no legal system-indeed no communicative system-can do without. It would not be possible to have law or even to conceive of law without embracing the practice of fact-finding. The anti-orthodoxy principle is not self-immolating, as a rejection of the idea of true and false facts would necessarily be ("there is no such thing as a true or false fact-and that's a fact"). The anti-orthodoxy principle repudiates the concept of heresy; it does not repudiate the concept of fact.

This is probably why Justice Jackson limited his statement of the antiorthodoxy principle to "matters of opinion"-i.e., as distinct from matters of fact. But the term "opinion" is at best a shorthand here. It is both overbroad and underbroad.

It is overbroad because there can be opinions on matters of fact. As a result, in appropriate settings, the falsity of opinions can be policed by the state, and a false "factual opinion," like other false statements on matters of fact, can be made into the basis of legal liability. This explains in part why doctors can be sued for negligent medical opinions.

But the term "opinion" is also obviously underbroad, because the term

116. Gertz v. Robert Welch, Inc., 418 U.S. 323, 339 (1974) (emphasis added). 
suggests a particularized propositional belief, and we have already seen that the First Amendment protects much more than "particularized messages." To complete the picture of the domain of expression to which the anti-orthodoxy principle applies, the distinction between fact and opinion would have to be supplemented by a host of related distinctions, all seeking to differentiate the domain of the factual from other domains, and all notoriously problematic: the distinction between fact and value, fact and theory, fact and fiction, fact and interpretation, fact and fancy, is and ought, objective and subjective, and so on.

The immense difficulties entailed by every one of these dichotomies need hardly be mentioned. Some people consider the existence of God to be a fact. Some philosophers believe in moral realism. Does the First Amendment's protection of religious speech or moral philosophy depend, therefore, on a finding by judges that God and morality are not, in fact, matters of fact?

Current doctrine correctly solves this problem to some extent by holding that government can punish speech as false only when it can prove falsity. This burden of proof allows the fact/opinion determination to be sidestepped in most cases. If the state cannot prove the falsity of polytheism, it cannot punish polytheism as false, regardless of anyone's view about whether the existence of gods is a matter of fact. ${ }^{117}$

But the very idea of "proving falsity" here already privileges conventional, secular, scientific methods of verification. Which is to say: A certain orthodoxy is irreducibly in play when we permit government to police any truth, even the banal, secular truths of salesmen, slanderers, and trial witnesses. It is pointless, however, to charge the anti-orthodoxy principle with a selfcontradiction in this regard.

Anti-orthodoxy is a modern, Western principle, carrying with it a modern, Western metaphysics-in particular, the commitment to the epistemic supremacy of science. Within this metaphysics, it is understood that certain claims to knowledge are not as good as others. Belief in a particular God is of course the inaugurating type of this kind of inferior knowledge claim, but before too long the same sorry epistemic status comes to be occupied by the claims of art, morality, philosophy, emotion, and so on. The irony is that this worldview, deeming only objectively verifiable facts to be solid enough to punish people for misrepresenting them, ends by creating a fundamental right to express the very ideas and attitudes that are supposed to be epistemically underprivileged. It is as if somehow, almost perversely, the translucent claims of spirit and feeling, banished from the world of accredited fact, thereby find their way to a deeper, more important, more protected domain than will ever be occupied by those propositions of sufficient solidity to be pronounced true or

117. Cf., e.g., Milkovich v. Lorain Journal Co., 497 U.S. 1, 11-20 (1990) (holding in a defamation case that statements which are not provably false receive "full constitutional protection"). 
false in courts of law.

The anti-orthodoxy principle begins, therefore, with a distinction between doxy and data, between opinion and fact. There can be no blasphemy in American law, but there can be lies, misrepresentations, failures to disclose material information, breaches of confidentiality, and so on. The antiorthodoxy principle simply does not apply in categorical fashion to "matters of fact." It applies rather, despite all the precautions that have to be erected around these terms, to the world of meaning, of ideas, of feeling, of the ineffable, of spirit- to every act of human imagination.

And it holds, within this domain of expression, that no one can be punished for speaking in violation of a government-established canon, no matter how this canon is articulated: whether in terms of good and evil, true and false, moral and immoral, safe and dangerous, healthy and harmful, or any other standard.

Imagine a nation determined to treat each person's opinions as legally equal. (This equality is what ultimately explains the links between First and Fourteenth Amendment jurisprudence.) So that the law has no power to tell anyone what to think. So that each person is free to express himself without fear that his beliefs or feelings or imaginings will be deemed unspeakable by law. Such is the commitment that the anti-orthodoxy principle attempts to capture.

But where does the anti-orthodoxy principle come from?

Not from moral philosophy. Nor from rumination on the necessary or ideal conditions of democracy. These are not the appropriate starting points of constitutional interpretation. The anti-orthodoxy principle emerges from the First Amendment's paradigm cases. Here are three such cases, three state actions that have become firmly established, core violations of the freedom of speech: suppressing revolutionary dissent, criminalizing blasphemy, and censoring art. These paradigm cases furnish the kind of constitutional "fixed stars" to which Justice Jackson referred.

From the paradigmatic status of revolutionary political dissent comes the proposition that even the real possibility of bloodshed does not justify the suppression of protected speech. From the paradigmatic status of religious speech comes the proposition that government cannot erect any canon of right and wrong thinking on a "matter of opinion." And from the paradigmatic status of art comes the proposition that the First Amendment protects the expression not only of particularized messages, but of the entire universe of human feeling and imagining too.

I will not defend here paradigm-case reasoning as a method of constitutional interpretation. ${ }^{118}$ I note only that it is: (1) deeply ingrained in

118. For a more detailed discussion of paradigm case interpretation, see JED 
American constitutional law; (2) historical without being originalist; and (3) self-consciously, irreducibly normative. The last point simply means that the paradigm cases never dictate, algorithmically, any particular principle. Deriving a principle from paradigm cases requires an act of judgment. This judgment aspires to justice, but not in the sense of trying to arrive at timeless truths of moral or political philosophy. It tries to do justice to the nation's acts of constitution-writing as inviolable commitments whose core meaning is given by their paradigm cases. A theory of the First Amendment should not try to say what the freedom of speech must mean to all reasonable minds, to all liberal states, or even to all countries that recognize such a freedom. It should aspire rather to say what the freedom of speech means to this nation, as we have committed ourselves to it, through our constitutional past and for our constitutional future.

The fact that political dissent, religious speech, and art are central instances of protected expression does not logically dictate an anti-orthodoxy principle. Paradigm cases almost never logically compel one particular interpretive principle. But the anti-orthodoxy principle responds to and captures these paradigm cases in compelling fashion-in a way that does them justice.

There is, however, an alternative interpretation that deserves consideration. It is a species of cost-benefit analysis and was encountered earlier. This view holds that speech of high social value is entitled to the fullest First Amendment protection, with speech of lower value receiving less protection or perhaps none at all. Political dissent, religious speech, and art, from this point of view, are paradigmatic examples of protected speech precisely because they are categories of speech of the highest social value.

This high-value/low-value approach has the additional advantage, it might be said, of providing an easy answer to the problems of unprotected speech. False speech, for example, has little or no value; that is why (it might be said) libel, fraud, perjury, and so on can be constitutionally prohibited. Because this high-value/low-value approach provides an important alternative to purposivism, and because it resurrects the cost-benefit analysis that purposivism repudiates, it deserves brief further consideration.

\section{B. Low-Value Speech}

The leading judicial formulation of the high-value/low-value approach to the freedom of speech remains a passage from Chaplinsky v. New Hampshire, decided almost sixty years ago:

There are certain well-defined and narrowly limited classes of speech, the prevention and punishment of which have never been thought to raise any Constitutional problem. These include the lewd and obscene, the profane, the

RuBENFELD, FREEDOM AND TIME chs. 10-11 (forthcoming May 2001). 
libelous, and the insulting or "fighting words".... It has been well observed that such utterances are no essential part of any exposition of ideas, and are of such slight social value as a step to truth that any benefit that may be derived from them is clearly outweighed by the social interest in order and morality. ${ }^{119}$

This passage actually suggests two different thoughts. The first is that speech is protected by the First Amendment only if it is "an essential part" of the "exposition of ideas" or in some other fashion of significant "value as a step to truth." But this thought cannot really be taken seriously-not, at least, by a First Amendment jurisprudence that accords a central place to art. Once the "painting of Jackson Pollock, music of Arnold Schoenberg, or Jabberwocky verse of Lewis Carroll" comes to be seen as "unquestionably shielded," 120 the Chaplinsky rhetoric becomes very difficult to sustain. Is it really plausible to say that the works just listed command their constitutional protection because they play an "essential part" in the "exposition of ideas" or because of their value as a "step to truth"?

In fact, religious speech-prayer, for example-should long ago have demanded repudiation of the notion that core, protected speech had to be a "step to truth." Does prayer satisfy this criterion? Conceivably it does, but surely its constitutional protection does not turn on its doing so. A person is free to pray to whatever God he can; it is precisely because prayer, in a certain sense, is not a step to truth or falsity in a conventional sense (it does not assert verifiable or falsifiable propositions in the conventional sense) that the state cannot constitutionally regulate it. And this is so not merely as a matter of free exercise. A law censoring religious speech would today be regardedcorrectly-as a paradigmatic violation not only of the freedom of religion, but also of the freedom of speech.

But the second thought expressed in Chaplinsky-that speech gains or loses First Amendment protection in proportion to its "social value"-is arguably perfectly consistent with the paradigmatic status of prayer and art as instances of protected speech. After all, what subject could be more important to man than the fate of his soul? And even if nearly no one listens any more to Schoenberg's tone poems, who would be so bold as to cast doubt on the "social value" of a canonical work of modern composition? Doesn't the Chaplinsky high-value/low-value approach therefore remain intact, even after the Court's "exposition of ideas" and "step to truth" rhetoric has been put aside?

The freedom of speech, as we actually know it and have it in this country, is irreconcilable with high-value/low-value thinking. Consider pornography. I refer here not to Lady Chatterly's Lover or the Starr Report but to the run-ofthe-mill sex-trade material available at the newsstand or on the internet. This material maintains its constitutional protection by staying just slightly less

119. Chaplinsky v. New Hampshire, 315 U.S. 568, 572 (1942).

120. Hurley, 515 U.S. at 569. 
"offensive" than obscenity. No court has ever claimed that pornography of this sort is protected because of its high "social value," whatever that might mean. On the contrary, pornography is protected on the basis of a simple principle that has nothing to do with measuring its "value": It is protected on the ground that, with almost no exceptions, speech cannot be constitutionally banned merely because a legislative majority finds it offensive.

If speech were really entitled to protection in proportion to its "social value," then, at the very least, run-of-the-mill pornography should be accorded only minimal First Amendment protection, so that, for example, laws regulating the sale of pornography to adults should be subjected to a level of review considerably more lenient than those applicable to regulations of "high value" political speech. But on the contrary, with the arguable exception of commercial speech, all protected speech, from pornography to political dissent, is treated formally alike in First Amendment law. The same "strict scrutiny" that applies to laws regulating "political speech" applies to pornography laws.

Would free speech law be better off if it accorded less protection to pornography (and other material of "low social value"). Try to imagine a First Amendment jurisprudence in which judges were really called upon to portion out constitutional protection depending on their assessment of the "social value" of the speech act or speech "category" at issue. This was the point of the earlier discussion concerning "sports speech" or "weather speech." If highvalue/low-value thinking were taken seriously, a person could in principle be jailed for calling Roger Clemens a bum.

The real problem, however, with the high-value/low-value approach is not that judges would have a hard time assessing the "social value" of the various "speech categories" or, for that matter, assigning speech acts to their correct "category." The problem is that judges who engaged in these exercises would be violating the constitutional guarantee they are supposed to be interpreting.

The First Amendment forbids governmental actors from doing what the high-value/low-value approach calls on judges to do. It forbids governmental actors-judges included - from declaring an opinion to be of low value and, on that basis, applying the coercive power of law against someone because he has expressed that opinion. The Chaplinsky approach to free speech is, in this sense, unconstitutional.

This conclusion should not be surprising. We would see the point straightaway if a religion or a religious practice were at issue. Imagine an exotic religion, unfamiliar to most Americans, whose practitioners believe their leader is infallible and in their services drink a liquor that they say not only represents, but actually is, the blood and body of their dead savior. Imagine now that a judge enjoins this practice. His reasoning is, in the alternative, (1) that this religion as a whole has such low social value (whether "as a step to truth" or by any other measure) that the First Amendment does not protect it, or 
(2) that the ritual eating of a human being's body is in particular a religious practice of such low value that it need not be protected. If we are candid, we will understand that our objection to this holding would be prompted not by a certitude that the judge had made an empirical mistake about the amount of "social value" involved. Our objection would be prompted by the judge's very supposition that he was entitled to measure the "social value" of a particular religion or religious practice and to mete out the law's prohibitory force on this basis. The high-value/low-value approach to protected speech is no different, and we ought to reject it for the same reason.

(But couldn't a state ban a religious practice that involved real human sacrifice? Of course, but not because a state or judge deemed this practice to be of low religious "value." A state can ban human sacrifice in a religious service because and to the extent that it bans homicide generally, without regard to the religious nature of the conduct.)

In free speech doctrine, the same flaw in high-value/low-value thinking is demonstrated by the categorical protection afforded to dissenting political opinions. Someone says that blacks or Jews are a canker on the body politic, and the government should therefore exterminate them. This speech act is definitely "political." In fact it is political dissent on a matter of tremendous public concern. It is unquestionably protected by the First Amendment. But does this opinion have any social value?

Possibly, but even if so, how can anyone purport to say with confidence that its "value" exceeds its costs? If we are to regard such speech as entitled to full constitutional protection, the reason cannot be a firm conviction that it is too socially valuable to be suppressed. If there is one opinion in the world whose destructiveness may fairly be taken as established, it is the opinion just described.

Someone will reply that it is not the viewpoint whose value is to be measured, but rather the "category" of "political speech." Why? What would force a cost-benefit First Amendment judge to accept "political speech" as the relevant category of speech to be measured? The only possible answer would have to invoke "slippery slope" arguments, but the slope here is far from frictionless. A state could easily enact a law declaring "racist speech" to be prohibited, and a balancing judge could easily uphold it, deeming this speech "category" to be so lacking in "social value" that it deserves no protection. Racist speech would be no harder to define-in fact probably a good deal easier to define-than political speech.

To be sure, racist speech might be said to be a viewpoint-based category. But the whole problem here is that the cost-benefit approach offers no adequate explanation of the categorical First Amendment principle against viewpoint discrimination. The reason the First Amendment protects racist speech has nothing to do with its "social value." The reason is that the First Amendment 
forbids state actors from censoring any opinion on the ground that the opinion is of insufficient value, immoral, dangerous, or otherwise undeserving of constitutional status. In the eyes of the Constitution, there is no such thing as a low-value opinion. That is why Nazi opinions cannot be banned. It is also why a person cannot be penalized for expressing an opinion about the weather. And it is also why distinctions between "high" and "low" art have no place in First Amendment law.

Throughout the domain of expression to which the anti-orthodoxy principle applies, no prohibitions can be enforced on the basis of state determinations of what expression is and is not valuable enough to merit full First Amendment protection. Just as no person can be punished for expressing an opinion deemed of insufficient "social value," so too no one can be punished for expressing low-value feelings, theories, imaginings, and so on. The highvalue/low-value approach to the freedom of speech should be entirely rejected.

\section{Clear and Present Danger}

An objection: Aren't people in fact punished for speaking in many contexts? Incitement to riot, for example, is a crime that can consist entirely of speech acts. Does purposivism mean that incitement laws are unconstitutional?

No, but both to see why and to see the force of the objection, it is essential to remember what reply I cannot make. I cannot say that the ultimate purpose of an incitement law is merely to prevent illegal conduct. To repeat: A permissible ultimate legislative purpose (or motive) does not negate an impermissible immediate purpose. Incitement laws purposefully single out certain speech acts for punishment. They unquestionably punish persons for speaking. It is irrelevant, from a purposivist perspective, that they do so in order to prevent crime, just as it is irrelevant that a law censoring political criticism might be enacted in order to prevent crime.

There is once again a direct analogy here between the First and the Fourteenth Amendments. If Mississippi reenacted its black codes today, the state would not be heard to defend itself with the claim that its statute would reduce violence. Perhaps this claim would be true; perhaps Mississippi's legislators might even have been motivated by the desire to reduce violence. But the law would still purposefully discriminate against blacks, and the fact that this purposeful discrimination might itself be supposed to serve further state purposes would be wholly irrelevant, no matter how legitimate these further purposes may be. The same reasoning applies to laws deliberately suppressing protected speech.

But couldn't I say that incitement is not protected speech? No. This response would beg the question. The advocacy of unlawful conduct is protected by the anti-orthodoxy principle, as it is by established doctrine. If 
advocating unlawful conduct were unprotected per se, Karl Marx could be banned. The question, then, is why advocacy of unlawful conduct that amounts to "incitement" is unprotected.

The reason, a balancer would say, is obvious. "When someone advocates unlawful conduct in front of an aroused mob," the balancer would say, "the potential harms are so great that they outweigh whatever First Amendment value his speech might otherwise have. That is what Holmes's clear-andpresent-danger test was all about. That is what contemporary strict scrutiny doctrine, allowing protected speech to be prohibited whenever necessary to serve compelling state interests, is all about as well. The freedom of speech must yield in the face of clearly threatened, significant harms. You cannot explain the constitutionality of incitement laws without acknowledging this simple fact."

Notice that this cost-benefit explanation of unprotected speech differs from the low-value approach just discussed. No longer is the judge called on to assess the relative "social value" of various speech acts or speech categories. The focus now is not on the putatively low value of certain speech acts, but on their putatively great harms. The balancer will say that this way of thinking explains the unprotected status not only of inciting speech, but of other, related categories of unprotected speech that threaten to lead to unlawful conduct (fighting words, threats, solicitation of crimes, and so on) and that all seem to exemplify a clear-and-present-danger exception to First Amendment protection.

But Holmes's famous test, which purposivism embraces, is very different from cost-benefit strict scrutiny, which purposivism rejects. Cost-benefit strict scrutiny is inconsistent, as I have said, with the First Amendment's paradigm cases. The clear-and-present-danger test, at least if interpreted in a certain way, is not. It is not even a version of cost-benefit analysis. Current incitement law provides the clearest example.

In the well-known Brandenburg case, the Supreme Court held that advocacy of unlawful conduct could be criminalized only if the speech was intended and likely to induce imminent unlawful conduct. ${ }^{121}$ Under Brandenburg, speech that advocates lawbreaking can be punished only when it is like the proverbial match held to the tinderbox-or only, to use another familiar image, when it is like falsely shouting fire in a crowded theater. What is decisive about the Brandenburg formulation is that it allows speech to be prohibited not because of its harmfulness, but because the speaker seeks there and then to bring about a particularized, prohibited, and prohibitable course of conduct.

What does this mean?

121. Brandenburg v. Ohio, 395 U.S. 444, 447 (1969) (per curiam). 
Consider another "unprotected speech category," which almost never registers on First Amendment radar screens. I am robbing a bank. You are my lookout. From a street corner a couple of blocks away, you tell me by cellular phone that the police are coming. That is your only role in the robbery; all you do is speak certain words. For those words, you can be jailed.

Why does this situation raise no First Amendment problem? Because through your speech, you participated in a prohibited (and prohibitable) course of conduct. So long as the state bans bank robbery in general, it can constitutionally punish everyone who participates in a bank robbery-including people who participate in a bank robbery through words.

Everyone knows that First Amendment issues arise when people use prohibited conduct to engage in expression. That is the situation to which $O^{\prime} B$ rien typically applies. ${ }^{122}$ What is less well understood, but equally well established, is that First Amendment issues can fail to arise when people use words to engage in prohibited conduct.

We do things through words. One of the things we do is participate in courses of conduct. If one of these courses of conduct happens to be against the law, and if the prohibited course of conduct is not itself constitutionally protected, we can be punished for our participation in it so long as the law treats alike those who participate through word and deed. Just as nonverbal conduct is entitled to First Amendment protection when used to engage in protected expression (and when the state punishes the person because of what he said), so too words can lose their protection when used to engage in prohibited conduct (and when the state punishes the person because of what he did).

From this point of view, Brandenburg makes good sense. When someone intentionally uses speech to bring about imminent unlawful conduct, and it is likely that this result will ensue, he is properly treated as having engaged himself in, as having participated in, that course of conduct. He can be punished for that reason-and not because the harmfulness of his speech outweighs its benefits. The same line of thought explains the unprotectedness of an entire set of speech acts "brigaded" with prohibited conduct: agreements to commit unlawful acts (conspiracy), solicitations of unlawful acts, threats, and so on.

This reading of Brandenburg may be novel, but it makes far better sense of the Brandenburg criteria than a cost-benefit reading can. On the cost-benefit account, Brandenburg's imminence and intentionality criteria superficially appear sensible because they seem to go to the probability that harm will ensue. But this appearance is deceiving.

A genuine cost-benefit account of speech that induces unlawful acts would

122. See text accompanying notes 3-9 supra. 
be concerned, on the cost side, essentially with two things: the magnitude of the threatened harms and the probability of their coming about. From a costbenefit view, the intentionality of the harms should be much less significant than their magnitude, a factor with which Brandenburg does not concern itself. As far as Brandenburg is concerned, a person who deliberately incites others to commit a minor offense is in the same position as a person who incites others to riot. In both cases, the speech is equally unprotected.

Perhaps a balancer might reply that unlawful acts are per se so harmful that the state need only show, in order to suppress or punish speech, that the speech was likely to cause such acts. But this kind of response only highlights the flaw in the cost-benefit reading of Brandenburg. If in the cost-benefit view, speech can be criminalized when it is likely to bring about imminent unlawful acts, surely speech ought also to be prohibitable when it is almost certain or proven to bring about unlawful acts down the road.

In other words, on a cost-benefit reading of Brandenburg, speech should also be prohibitable whenever the speech is known to cause others to commit acts of violence, even if the harm was not imminent and even if the speaker did not intend this result. Accordingly, a state should be able to ban a Spike Lee movie if it were conceded that the movie would cause a few members of its audience to commit acts of violence on leaving the theater. The Bible might as well be burned too, now that a couple of thousand years have demonstrated that the good book leads to occasional acts of religiously inspired killing.

Someone will object that the Bible and the movie are of such high First Amendment value that, unlike the mere advocacy of unlawful conduct, their benefits outweigh the harms they might cause. But this reply simply resuscitates the high-value/low-value approach to speech, which we have already rejected.

Despite appearances, the Brandenburg test cannot be understood as a balancing test. It should be understood rather as a test to determine whether an individual has intentionally used speech so closely and directly engaged with a particularized course of prohibited conduct that the individual may be treated as having participated in that conduct. Brandenburg is a clear-and-presentdanger test, not a compelling state interest test, where the latter implies that speech may be suppressed whenever it is likely to bring about significant harm. On the contrary, Brandenburg clearly implies that the probability that speech may bring about an unlawful act is not a sufficient constitutional basis for criminalizing it, unless the speech is so closely, immediately, and intentionally engaged with a particular unlawful act that the speech is itself part and parcel of that act, or an attempt (in the criminal law sense of the word) to bring it about. The line to draw here may often be a close and difficult one. But this is the line that Brandenburg polices. 


\section{Obscenity and Other Remaining Issues}

I have said little about it, but laws banning obscenity would almost certainly be unconstitutional under the theory I have been developing here. These laws ban expression solely because it is considered offensive, and the First Amendment does not permit that. But then obscenity is already constitutionally protected inside the home, ${ }^{123}$ and it is a strange, compromised constitutional jurisprudence that allows an individual to be jailed for buying what he has a constitutional right to possess. This does not mean, however, that government cannot regulate the dissemination of sexually explicit speech to keep it from children. That purpose could be constitutionally permitted even though the purpose of keeping the same speech from adults is not.

"Fighting words" would remain unprotected under the analysis described above, at least as the fighting words doctrine has come to be interpreted. Mere insults are not prohibitable under current doctrine. Instead, contemporary fighting words law is like contemporary incitement law. As in Brandenburg, the contemporary fighting words cases have narrowed the doctrine to such an extent that insulting speech becomes unprotected only when uttered in circumstances in which such speech is properly regarded as an attempt to commence a fight-a particularized, prohibited course of conduct. ${ }^{124}$

Commercial speech, however, could no longer be treated as a second-class First Amendment citizen. Regulating commercial speech to police its factual truth would not be problematic. Nor would regulating commercial speech that advertised unlawful conduct; if the conduct is unlawful, a specific proposal to engage in that conduct can be made unlawful too. But regulating commercial speech that truthfully advertises lawful conduct would be problematic. Where a course of conduct itself is not itself prohibited, speech attempting to induce people to engage in that conduct cannot be prohibited either. For here the exception just discussed-that speech may be prohibited when it participates in a prohibited course of conduct-does not apply. On the contrary, speech is here deliberately singled out for adverse legal treatment-speech is treated worse than the corresponding action-which purposivism does not accept. These conclusions may run counter to some of the language of the older commercial speech cases, but they are consistent with the recent cases, which arguably have arrived at this result already. ${ }^{125}$

I have not mentioned the problem of captive audiences at all. The freedom

123. Stanley v. Georgia, 394 U.S. 557 (1969).

124. See, e.g., Gooding v. Wilson, 405 U.S. 518 (1972).

125. See, e.g., Greater New Orleans Broad. Ass'n, v. United States, 527 U.S. 173 (1999) (striking down statute prohibiting television and radio broadcasters located in states where casino gambling is legal from carrying casino advertisements); 44 Liquormart, Inc. v. Rhode Island, 517 U.S. 484 (1996) (striking down statutory ban on advertising liquor prices). 
of speech includes rights of listeners as well as speakers. A purposivist account of free speech is, therefore, open to protecting captive audiences from unwanted speech, so long as this speech is prohibited on a par with unwanted conduct. For example, a speaker has no more right under the First Amendment to force his speech into another's home, against the occupant's will, than he has to force his body into that home. Thus telephone harassment laws can be perfectly constitutional, even though they clearly penalize people for speaking.

Finally, I have not mentioned the line of Supreme Court cases involving regulations of what Professor Post calls First Amendment "media."126 Post argues that laws enacted for genuinely speech-neutral purposes such as "preventing litter or raising revenue" have been and should be invalidated when their effect is to impose excessive burdens on "recognized media" of First Amendment communication-leafletting, newspapers, and so on. Post cites as "examples"127 Schneider v. State of New Jersey $y^{128}$ and Minneapolis Star $\&$ Tribune Co. v. Minnesota Commissioner of Revenue. ${ }^{129}$ These are the cases, according to Post, most clearly and appropriately exemplifying the need to strike down laws on the basis of their adverse communicative effects, rather than on the basis of any speech-targeting purpose. ${ }^{130}$

But the cited cases are not instances of speech-neutral laws being struck down because of their effects. They are instances of speech-targeting laws being struck down on their face. The law "preventing litter" in Schneider did not prohibit littering. It prohibited distributing any printed matter in any street, sidewalk, or park without a permit. ${ }^{31}$ The law "raising revenue" in Minneapolis Star was not a generally applicable tax. It was a "special tax," an "a paper and ink tax," that "applie[d] only to certain publications." 132 These were laws that singled out First Amendment activity for special legal liabilities.

In fact, the Court in Minneapolis Star specifically held that subjecting newspapers to a generally applicable sales tax would be constitutionally unproblematic, despite the fact that the "effective burden" of such a tax on newspapers might have been identical to, or even more onerous than, the burden imposed by the "paper and ink tax."133 The Court's holding was categorical: States could not "single out the press for a different method of taxation."134

126. Post, supra note 42 , at 1256.

127. Id.

128. 308 U.S. 147 (1939) (ordinance designed to prevent littering).

129. 460 U.S. 575 (1983) (use tax on paper and ink).

130. Post, supra note 42 , at $1256-58$.

131. Schneider, 308 U.S. at 148.

132. Minneapolis Star \& Tribune Co., 460 U.S. at 581.

133. Id. at 588 .

134. Id. 
Thus Schneider, Minneapolis Star, and other cases following them ${ }^{135}$ confirm the analysis provided here. They are not effects-test cases. They are not cases in which a party obtained a First Amendment exemption from a generally applicable conduct law. They are cases holding that states cannot impose special legal liabilities on people for engaging in a communicative activity.

There are a hundred other issues and difficulties that a purposivist First Amendment jurisprudence would have to address and might help to resolve. But these issues I leave to another day.

\section{CONCLUSION}

The alternative to purposivism is balancing. But if we really believe, as it seems so natural to believe, that First Amendment rights are a matter of weighing costs and benefits, then we are, ultimately, where Judge Posner is. And if speech is prohibitable whenever, as Posner puts it, "in American society its harmful consequences are thought to outweigh its expressive value," there is no longer a First Amendment at all.

135. See, e.g., Arkansas Writers' Project, Inc. v. Ragland, 481 U.S. 221 (1987) (striking down statute selectively imposing sales tax on some, but not all publications); $c f$. Arcara v. Cloud Books, Inc., 478 U.S. 697 (1986) (upholding, despite usual First Amendment bar against prior restraints, the shutting down of a bookstore under a generally applicable prostitution law). 